\title{
The Hindu Community in Muscat: Creating Homes in the Diaspora
}

\author{
SANDHYA RAO MEHTA and JAMES ONLEY
}

\begin{abstract}
This article looks at Muscat's Hindu community, part of the city's wider Indian society. It examines the diasporic home-making history, practices, and strategies that have created distinctly Hindu and Indian spaces in an Arab environment. It maps the community's demographics and human geography, presents a case study of the Khimji Ramdas family, considers the community's "permanent impermanence", and assesses the challenges posed to the community by the kafäla (sponsorship) system and other government restrictions.
\end{abstract}

Keywords: Muscat, Mattrah, Oman, Hindu, Indian, community, diaspora, home, human geography, kafala system

\section{Introduction}

Oman's population is very different from the other Gulf Cooperation Council (GCC) states, as it includes Hindu, Lawati, Zadjali, and Zanzibari nationals (citizens) who speak their own languages of Kachchhi, Khojki, Zadjali, and Swahili in addition to Arabic. ${ }^{1}$ This article examines Muscat's Hindu community: the oldest in the Gulf region. At its core is a longresident merchant class, known as the Banians/Banyans, formed over successive waves of migration since the early sixteenth century, if not earlier. In 2012, over 600 Banians held Omani nationality (citizenship) - more than any other state in the GCC. However, the vast majority of Hindus in Muscat are expatriates: some are diasporic, being multi-generational residents; others are migratory, having come to Oman relatively recently. While much has been written about the history of Muscat's Banian class, very little has been written about the

Sandhya Rao Mehta is Assistant Professor in the Department of English Language and Literature at Sultan Qaboos University, PO Box 42, Postal Code 123, Al Khoud, Sultanate of Oman, rao@squ.edu.om. James Onley is Editor of the Journal of Arabian Studies and Senior Lecturer in Middle Eastern History at the Institute of Arab and Islamic Studies, University of Exeter, Exeter, EX4 4ND, United Kingdom, j.onley@exeter.ac.uk; and and Visiting Associate Professor of History at the Doha Institute for Graduate Studies, Qatar, james.onley@dohainstitute.edu.qa.

Authors' note: We would like to thank Gamal M. Hendawy for providing the template map of the Muscat Governorate, and Vimal Purecha for the photo of the Ratansi Purshottam family firm from c. 1910 .

${ }^{1}$ While most Lawatis, Zadjalis, and Zanzibaris are fluent in Arabic, few Hindu Omanis are. The best modern survey of Muscat's demographics is Peterson, “Oman's Diverse Society: Northern Oman”, MEJ 58.1 (Winter 2004), pp. 31-51. 
Hindu community today, the main focus of this article. ${ }^{2}$ In 2012, there were roughly 86,000 Hindus living in Muscat and about 200,000 nationwide, part of a wider Indian society of $c$. 309,000 in Muscat and 718,642 in Oman that year. ${ }^{3}$ We describe the Indian community as a "society" in recognition of its size and complexity, being comprised of separate regional, linguistic, and religious communities, a microcosm of India itself.

Like other Middle Eastern countries, $99.9 \%$ of Indians in Oman have no permanent status in the country - their stay is directly linked to employment in the country. Bound by changing laws and employment circumstances, Indians live and work under precarious conditions with little idea of the length of their stay, just like all other expatriates in Oman. ${ }^{4}$ Their non-permanent status in the country is enforced through Oman's nationality law, which makes it nearly impossible for expatriates to obtain Omani nationality, and the kafäla (sponsorship) system, used by all GCC states, which requires expatriate work visas to be sponsored by a local employer - either a local institution or a national. The kafāla system prevents expatriates from switching jobs or, in many cases, leaving the country without the sponsor's approval. Even expatriate business owners are required to have a local sponsor and are thus bound by most of the same rules. ${ }^{5}$

Despite their non-permanent legal status in Oman, Indians dominate the spaces they occupy, owning them in cultural and social terms, making them more Indian than Omani - a home away from home, even an extension of India itself. They employ a range of practices to accomplish this. Indian society permeates every aspect of life in Muscat - from the migrant labourers about whom so much has been written, to the professional classes about whom far less is known, to the millionaire owners of multinational firms who appear regularly in the

2 There are only six studies of the Indians in present-day Oman: Deffner and Pfaffenbach, "Zones of Contact and Spaces of Negotiation: The Indian Diaspora in Muscat (Sultanate of Oman)", presented at the RC21 2011 Conference in Amsterdam, 7-9 July 2011 (available online); Deffner, "The Indian Diaspora in Oman", India Migration Report 2014: Diaspora and Development, ed. Rajan (2014), pp. 181-92; Pradhan, "Oman-India Relations: Exploring the Long-Term Migration Dynamics", Regionalizing Oman: Political, Economic and Social Dynamics, ed. Wippel (2013), pp. 107-28; Mehta, "Exploring 'Marginal' Diasporas: Indians in the Middle East", Dynamics of Diasporic Identity in Commonwealth Literature, ed. Nawale and Mukherjee (2013), pp. 258-78; Mehta, "Gendering the Gujarati Diaspora: Oral Narratives and Identity", Globalisation, Diaspora and Belonging: Exploring Transnationalism and Gujarati Identity, ed. Mawani and Mukadam (2014), pp. 42-57; plus a three-page section on Oman's Hindu citizens in Peterson, “Oman's Diverse Society: Northern Oman”, pp. 38-40.

${ }^{3}$ See section 6 below for details.

${ }^{4}$ The term "expatriates" or "expats" is commonly used in a discriminatory way in the GCC states, applied only to the professional classes, while labourers and service sector employees are regarded as "migrant labourers" and "migrant workers". Outside the Gulf, the term "expat" is often used for Westerners alone, revealing an assumption of superiority over nonWesterners.

${ }^{5}$ For more about the kafäla system, see Dito, "Kafala: Foundations of Migrant Exclusion in GCC Labour Markets", Transit States: Labour, Migration \& Citizenship in the Gulf, ed. Khalaf, AlShehabi, and Hanieh (2015), pp. 79-100. 
pages of Arabian Business and national newspapers. Muscat's Indian society asserts its presence both socially - through the wearing of Indian clothing, the use of Indian house décor, and large public gatherings (for worship, cricket matches, concerts, and classical dances) — and physically, through establishments like Hindu temples and Indian restaurants and shops.

Despite the prominence of Indian society in Oman, there are relatively few studies of it today. We attempt to address this gap by examining various aspects of this social group, including the diasporic home-making practices within Muscat's Hindu community. We begin with a brief discussion of the changing conceptions of "home" within diaspora and mobility studies, particularly as it relates to the Gulf. We then discuss the literature on Indians in the GCC states, followed by a look at Oman and Muscat's Indian and Hindu demographics. This is followed by a discussion of the historical role played by the Indian diaspora in Muscat and the way in which early migrants established themselves. We then outline the community's human geography. Next, we explore the ways in which working and professional class Hindus create and maintain their homes in the city today. We end with a consideration of how the Omani government's current and future plans and policies may negatively impact the fabric of Muscat's Indian society and home-making practices within it.

Our reason for focusing on Muscat's Hindus is because they self-identify as a social group within the city's wider Indian society, bound together through ties of religion, centred on the Hindu temples in Old Muscat and Ruwi, as well as a shared culture of celebrations. Within nationality-based diasporas and expatriate societies, it is common for social groups to form around a shared religion. Even those who never attended religious services back home sometimes find themselves attending them in their host country because of the central role the temple, mosque, or church plays for their group, providing a focal point for their social and cultural lives. Aside from the Hindu community, Muscat has several Indian Christian communities (Syriac Catholic, Malankara Orthodox, Anglican, Pentecostal, etc.) centred upon the churches in Ruwi and Ghala, a Sikh community centred upon the Sikh temple (gurdwāra) in Ghala, and Indian Muslim communities (Sunn̄̄, Ithnā'asharī, Nizārī, and Mustā‘lī) that naturally congregate at prayer times and participate in the same religious festivals. While Muslims congregate are on the basis of sect, not nationality, there are sub-sects unique to India, such as the Dawoodi Bohras, who maintain their own associations and prayer halls, and de facto Indian congregations can also be found in mosques frequented by Indian Muslims. Of course, religion is not the only aspect of one's identity - it forms part of a fluid spectrum, in combination with other elements. While someone may have a strong religious identity, another may have none at all.

Aside from being Indian, many Indians also identify themselves along regional and linguistic lines, such as Kachchhis from Gujarat. A strong regional and linguistic identity can see a person identify with others from the same group, regardless of religion, or others from the same group within their religion. Within Muscat's Hindu community, this can be seen in the form of region-specific festivals celebrated at the temples in Old Muscat and Ruwi such as Ganesh Puja of the Maharashtrians, Pongal of the Tamilians, and Durga Puja of the Bengalis — in addition to India-wide festivals like Holi and Diwali, and the daily prayers in which all Hindus participate. Before the 1970s, the temples celebrated only Kachchhi festivals - a reflection of the city's Hindu demographics before oil. Within Muscat's Indian Christian community, regional and linguistic identities manifest themselves as congregations (Malayali, Mangalorean, Kannada, Goan, Tamilian, etc.) of the Catholic and Protestant 
churches. In the case of small, single-congregation churches, we find de facto regional linguistic groups, such as the Malankara Orthodox Syrian Church whose congregation is entirely comprised of Malayalam-speaking Malayalis from Kerala. The Sikh community, being predominantly Punjabi, is also a de facto regional linguistic congregation. Within Muscat's Indian Muslim community, Indian-majority sects have their own associations and prayer halls, while the single-largest Indian Muslim sect in the city, the Mappilas of Kerala, maintain their own support organisation: the Kerala Muslim Cultural Centre in Ruwi. Even in secular settings, such as clubs and schools, one finds regional linguistic groups. This is perhaps most evident in the Indian Social Club, with its twenty regional linguistic wings Kachchhi, Gujarati, Marathi (or Maharashtra), Malayali (or Kerala), Goan, etc. - that organise regular social and cultural events (see Figure 1).

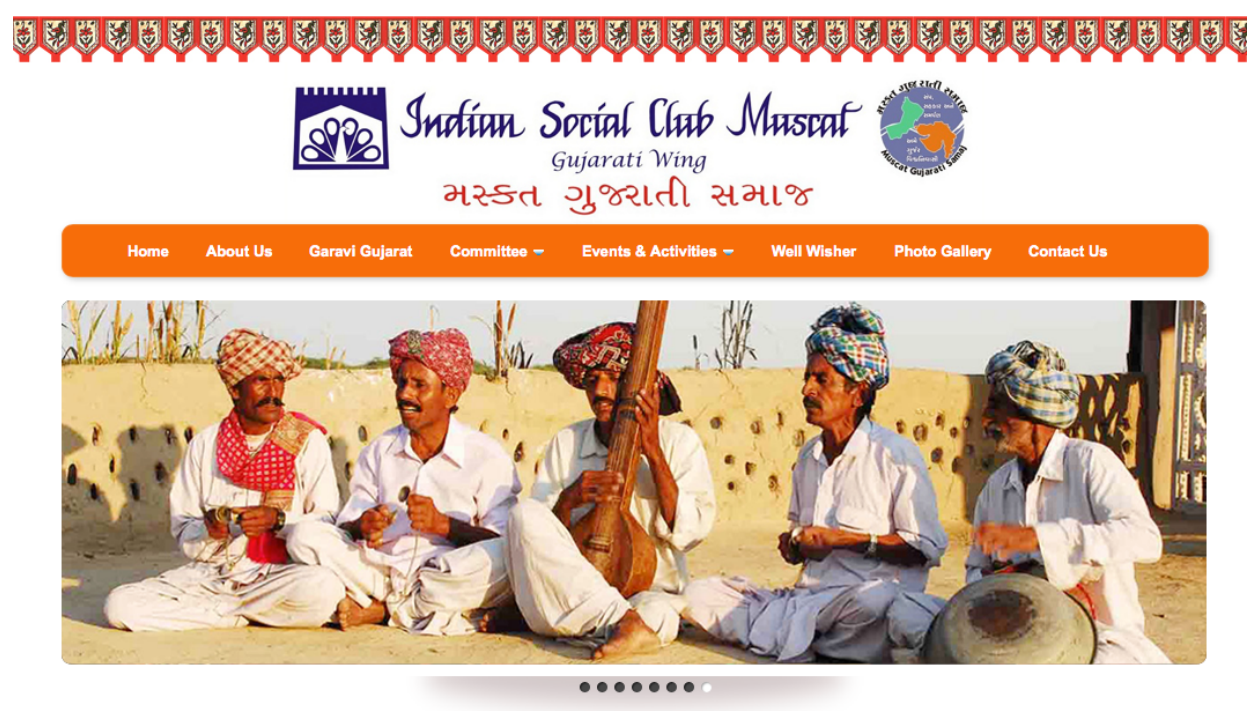

Figure 1: Website of the Indian Social Club's Gujarati wing, representing the oldest segment of Muscat's Indian society

Finally, Indian society in Muscat is also divided by class, with working and professional class Indians typically inhabiting separate areas of the city and living socially separate lives, as they do in India. Publicly, the lives of professional class Hindus intersect with their Muslim, Christian, and Sikh compatriots at the Indian Social Club and its events, the city's six Indian schools and their events, regular cricket matches and concerts, Indian Republic Day and Independence Day celebrations, and of course work and work-related social occasions such as official dinners and picnics, but privately, they also socialise on the basis of religion or region, or both. The lives of working class Hindus intersect with other Indians, both at work and in their shared dormitories, but they also socialise as a separate group in what little private time they have. The Indian diaspora thus reproduces the social living norms of India in terms of its linguistic and religious divisions.

This study defines "diaspora" as a permanent, long-established expatriate community or society united by a shared culture, the memory of a common homeland, and a desire to return to it. Since Muscat's Indian society is over half a millennium old, with a mixture of permanent and transient members, it can be described as diasporic or semi-diasporic. While "diaspora" is not often used to describe Indians in Muscat, since the vast majority of them are transitory migrants, the term more accurately reflects the ancient society they comprise, as 
well as its long-resident Banian class. We therefore use "diaspora" in our study alongside "society" and "community". 6

\section{Muscat's administrative divisions}

Before we examine the Hindu community in Muscat, an overview of the city's administrative divisions and neighbourhoods is necessary to make sense of the community's human geography. The Muscat metropolitan area, known as the Governorate of Muscat, or Muhāafazat Musqat, since 1991, consists of six wilāyahs (literally "provinces", although "districts" would be more accurate, given their small size) covering an area of 3,900 square kilometres. These are Muscat, Mattrah, Bawshar, Seeb, Amarat, and Qurayyat. Each wilāyah, in turn, is divided into several urban townships, villages, neighbourhoods, or suburbs comparable to London boroughs: once separate settlements that now form an integral part of the city. Wilāyat Muscat's main areas are Old Muscat (the original town of Muscat) and AlBustan. Wilāyat Mattrah's areas include the original town of Mattrah, plus Qurum, Darsait, Bayt al-Falaj, Ruwi, and Wadi al-Kabir. Wilāyat Bawshar's main areas include Shatti alQurum, Madinat Sultan Qaboos, Khuwair, and Ghala (see Figures 2 and 3). ${ }^{7}$

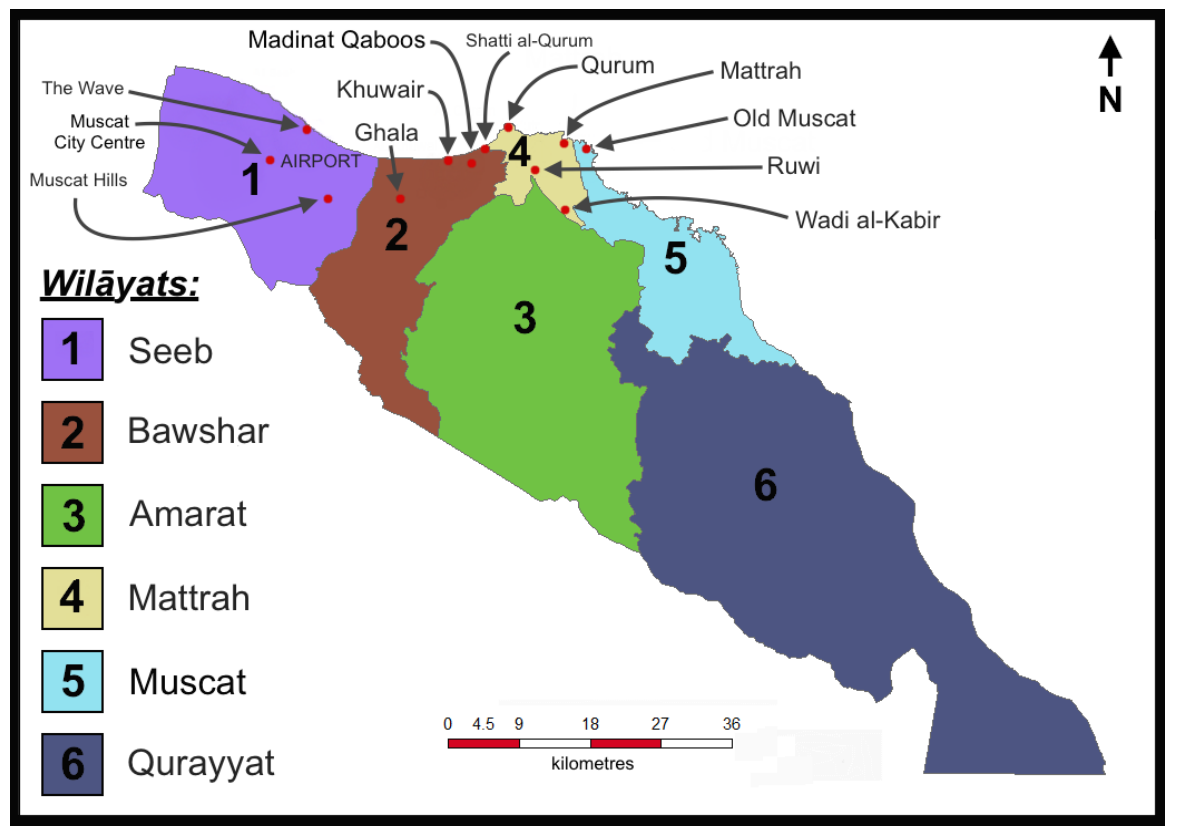

Figure 2: Governorate of Muscat wilāyahs (provinces)

(by James Onley \& Gamal Hendawy)

${ }^{6}$ For more on this, see: Safran, "Diasporas in Modern Societies: Myths of Homeland and Return”, Diaspora 1.1 (1991), pp. 83-4; Deffner, “The Indian Diaspora in Oman” (2014), pp. 186-90; Cohen, Global Diasporas: An Introduction, 2nd edn (2008), chaps 1, 9.

${ }^{7}$ For more details, see the governorate's website: http://gom.gov.om. Neither the official nor the popular spellings of Omani place names correspond to standard Arabic transliteation. For instance, Musqat (مسقط) is always spelt Muscat on government signs and websites, while Matrah (مطرح) is usually spelt Mattrah, Muttrah, or Mutrah, and Būshar (بوشر) often appears as Bawshar, Bawsher, Bowsher, Bousher, or Bausher. 


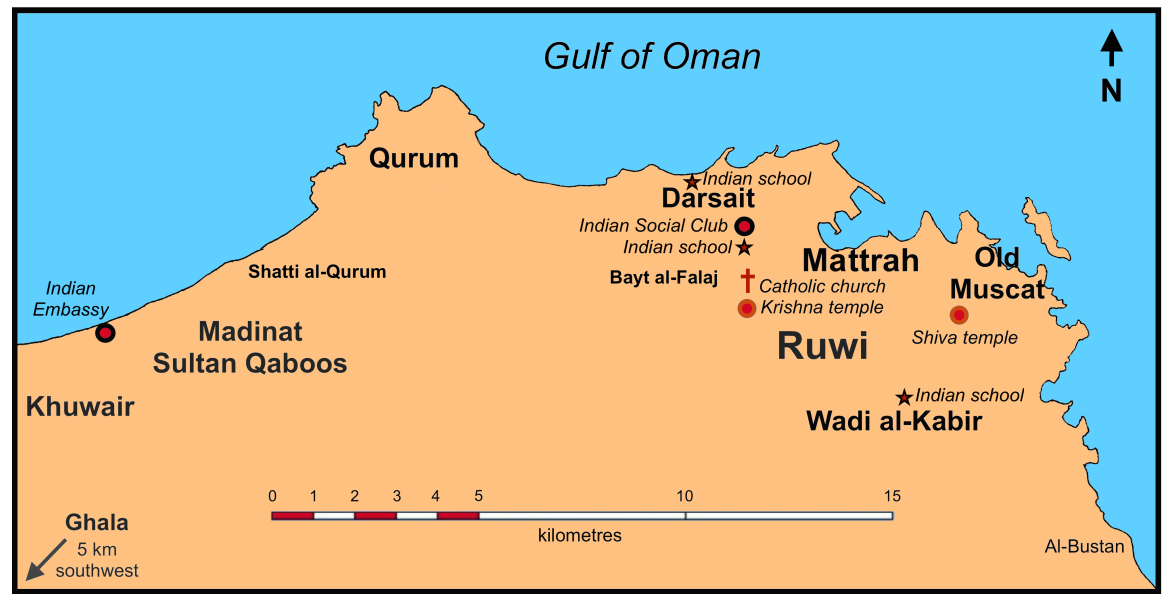

Figure 3: Neighbourhoods of the central Muscat metropolitan area (by James Onley)

Muscat's notable absence of mega shopping malls, glass skyscrapers, and, until recently, gated communities, sets it apart from other cities in the Gulf Cooperation Council (GCC) states. While these cities have developed along Western lines, with grid planning and modern tower blocks, Muscat has developed along relatively modest lines, more like Manama than Dubai or Doha, with neighbourhood communities having a much greater social continuity with the past. This is due, in part, to the fact that Oman has the GCC's lowest GDP per capita in relation to its national (citizen) population, a result of it having the GCC's second-highest national population after Saudi Arabia - over 2.3 million in 2015 - and relatively low oil and gas reserves.

\section{Overseas Indians (NRIs, PIOs): some definitions and considerations}

The mobilities paradigm in human geography, together with diaspora studies (with its focus on the importance of home/homeland), offer one of the most fruitful approaches to the study of Indians in Muscat, where community-formation and society-formation are interlinked with continued mobility and transnationalism. ${ }^{8}$ Thomas Faist advises us to view migration and diaspora, not just in terms of a single migration from the homeland to the hostland, but also in terms of the migrants' continuing ties to their homeland. ${ }^{9}$

For Indians, this is most clearly illustrated by the Indian government's own definition of overseas Indians, whom it places into one of two categories: Non-Resident Indians (NRIs)

${ }^{8}$ See, for instance, Sheller, "The New Mobilities Paradigm for a Live Sociology", Current Sociology Review 62.6 (2014), pp. 789-811; Tölölyan, "The Nation-State and Others: In Lieu of a Preface", Diaspora 1.1 (Spring 1991), pp. 3-7.

${ }^{9}$ Faist, "Introduction", Diaspora and Transnationalism: Concepts, Theories and Methods, ed. Bauböck and Faist (2010), p. 12. 
and Persons of Indian Origin (PIOs). ${ }^{10}$ Both NRIs and PIOs are defined in terms of their continuing relationship with India. NRIs are Indian citizens subject to a separate tax status in India due to their non-residency in the country. They are regarded by both their homeland and hostland as temporary migrants from India, even if that temporariness lasts a lifetime and can span generations, so long as they do not take up the citizenship of another country. NRIs remain connected with India in at least two important ways: personally, through their culture and family back in India, and legally, through their citizenship and financial accountability to the Indian state. PIOs, on the other hand, are members of the Indian diaspora without Indian passports who still maintain ties with India. Although holding foreign citizenship, they enjoy many of the same non-political rights as NRIs, they require no visa to visit or work in India, and are eligible for Indian citizenship if they relinquish their other citizenship. ${ }^{11}$ The economic importance of NRIs and PIOs is so great - they remitted over US\$70 billion to India in 2014, for instance - that the Indian government created the Ministry of Overseas Indian Affairs in 2004 to manage India's relations with them.

A common pattern among overseas Indians is the way in which they retain their ties to India through annual return visits home (if possible) and daily imaginative reconstructions of their homeland in the hostland. Alison Blunt observes that one's diasporic home is not just created physically, with objects from one's homeland, it is also "shaped by everyday practices, lived experiences, social relations, memories and emotions". ${ }^{2}$ Anh Hua also observes that one can re-create a distant or lost homeland by reliving their memory of it through "Literature, film, satellite TV shows, Bollywood, photography, dance, music, performance arts, languages, folklores, cultural myths, rituals, religious texts, newspapers, independent community press, Internet blogs and websites, collectables and souvenirs and so on". ${ }^{13}$

Hua also argues that current definitions of citizenship - and its denial, in the case of the GCC states - are not adequate to describe the various forms of belonging within a nation state and that

what needs to be made visible is the contradiction, tension, and exclusionary tendencies in citizenship practices as found in classical citizenship rooted in the nationstates, and the need to expand our understanding of citizenship to include other multiple modes of belonging and political membership in various communities at the local, national, and supranational levels. ${ }^{14}$

${ }^{10}$ In 2006, the Indian govt introduced a parallel category to PIO: the Overseas Citizen of India (OCI) scheme, which is a modified version of the PIO scheme. In Jan. 2015, it discontinued the PIO scheme and now treats all PIOs as OCIs. We have chosen to use PIO in this article, however, in the interests of consistency, to avoid confusion.

${ }^{11}$ For more details, see the Ministry of Overseas Indian Affairs website: http://moia.gov.in/ services.aspx id $1=35 \& i d=$ m $3 \& i d p=35 \&$ mainid $=23$

${ }^{12}$ Blunt, “Cultural Geography: Cultural Geographies of Home”, PHG 29.4 (2005), p. 506.

${ }_{13}$ Hua, "Homing Desire, Cultural Citizenship, and Diasporic Imaginings", JIWS 12.4 (2011), p. 45.

${ }^{14}$ Ibid., p. 53. Hua draws on the work of Ralph Pettman and Young-Chul Cho. 
One way Hua suggests to expand our understanding of citizenship is to analyse its cultural practices and production. ${ }^{15}$ This is a fruitful way to study the Gulf's migrant communities for whom neither local citizenship nor permanent residency are available (except to a tiny minority), regardless of the length of stay in the host country. In the absence of legal citizenship, members of these communities have created another form of belonging, both to their place of residence as well as to each other, through a variety of private and public practices - a form of belonging Hua calls "cultural citizenship". ${ }^{16}$ It is cultural citizenship that ties a diasporic community together in a given city, such as the Hindus of Muscat.

\section{Methodology}

This paper is based on the lead author's interviews with twenty-five members of Muscat's Hindu community. Interviewees included twelve women: three teachers, four stay-at-home mothers, and five housemaids; and thirteen men: four members of the old Hindu merchant class from Gujarat, a general manager of a construction company, five migrant labourers from a commercial cleaning company, and three repairmen (plumbers, electricians) working in a shop. They were chosen to represent each class of Muscat's Hindu community. Their residence in Oman ranged from five years (in the case of labourers) to more than thirty-five years (in the case of Banian merchants who were born in India, but who returned to their homes in Muscat soon after). They came from different parts of India: nine from Gujarat State, two from Maharashtra State (but from Gujarati families), seven from Kerala State, four from Delhi, and three from Andhra Pradesh State.

The interviewees were asked questions about their perception of Muscat over the years, where they spent their annual holidays and short breaks, their relationship with Omanis professionally and privately, how they spent their earnings, and their future plans regarding their stay in Muscat. They were also asked questions about their shopping habits, restaurants visited, as well as their source of daily news. Most of the interviews with women were conducted in their homes, which offered insights into the cultural artefacts used to create diasporic homes in private and semi-private spaces, such as apartments and their adjacent corridors.

Aside from the interviews, this study is also based on the lead author's fifteen years' of personal interactions with members of the Hindu community at social events, private gatherings, religious services, and sporting events, as well as an extensive examination of articles from two Muscat-based English language newspapers that cater to an Indian readership, the Times of Oman and the Muscat Daily. Cultural representations and practices such as writings, decorative objects, images, music, and performance were also analysed for this study. The insights gained from these multiple perspectives and avenues of investigation have revealed a range of practices employed by Hindus in Muscat to belong to a city that views them as guests - non-permanent/temporary residents - even if they were born there or have spent a large part of their lives there.

\footnotetext{
${ }^{15}$ Ibid.

${ }^{16}$ Ibid., p. 51.
} 


\section{Literature on Indians in the Gulf}

Within the field of Indian diaspora studies, the GCC states are relatively understudied. ${ }^{17}$ Most studies of Indians in the Gulf over the past four decades have taken a macro socio-economic and political approach, focusing on population statistics, remittance flows, government policies, and the like. ${ }^{18}$ The socio-cultural experience of Indians in the Gulf, however, has only recently been examined at any length. Most of these studies focus on the United Arab Emirates and Bahrain; Oman has remained relatively peripheral to the wider discussion. ${ }^{19}$ The best-known book-length studies are of the UAE and Bahrain, written by Syed Ali, Neha Vora, and Andrew Gardner. Syed Ali's Dubai: Gilded Cage (2010) examines the lived experience of Indians in Dubai, focusing on the plight of the labourers as well as the global world of Dubai's Indian middle class who employ imaginative strategies to manage their "permanent impermanence" in the UAE. Neha Vora's Impossible Citizens: Dubai's Indian Diaspora (2013) investigates identity and belonging amongst Dubai's Indian middle class, and finds that many Indians see Dubai as an extension of their homeland, as an Indian city. Andrew Gardner's City of Strangers: Gulf Migration and the Indian Community in Bahrain (2010) tackles the structural violence of the kafāla system, middle class strategies to manage their permanent impermanence, and the social organisations and institutions of Bahrain's Indian society. ${ }^{20}$ Among the few studies of Indians in Oman today is the work of Veronika Deffner and Carmella Pfaffenbach, who examine the non-material spaces negotiated by Indians in

${ }^{17}$ For more about the history of the Indian presence in the Gulf region, see Onley, "Indian Communities in the Persian Gulf, c.1500-1947", The Persian Gulf in Modern Times: Ports, Peoples and History, ed. Potter (2014), pp. 231-66.

18 See, for instance, Jain and Oommen (eds), South Asian Migration to Gulf Countries: History, Policies, Development (2015); Abraham, "India and its Diaspora in the Arab Gulf Countries: Tapping into Effective 'Soft Power' and Related Public Diplomacy”, Diaspora Studies 5.2 (2012), pp. 124-46; Winckler, "The Challenge of Foreign Workers in the Persian/ Arabian Gulf: The Case of Oman", Immigrants \& Minorities 19.2 (2000), pp. 23-52; Weiner, "International Migration and Development: Indians in the Persian Gulf", PDR 8.1 (1982), pp. 1-36. India's Ministry of Overseas Indian Affairs Research Unit on International Migration at the Centre for Development Studies in Thiruvananthapuram, Kerala State, publishes the most comprehensive economic and demographic information on Indians in the Gulf, such as Irudaya Rajan's India Migration Report (published annually since 2010). For more information, see: www.cds.edu.

19 In 2012, the Indian govt published a census of Indians the the GCC states, listing 5,687,032 people (NRIs and PIOs combined): 1,789,000 in Saudi Arabia, 1,750,000 in the UAE, 718,642 in Oman, 579,390 in Kuwait, 500,000 in Qatar, and 350,000 in Bahrain. See: http://moia.gov.in/writereaddata/pdf/NRISPIOS-Data(15-06-12)new.pdf

${ }^{20}$ Aside from their books, Gardner, Vora, and Ali have all published numerous articles on the socio-cultural experience of Indians in the Gulf. See, for instance, Vora's "Producing Diasporas and Globalization: Indian Middle-Class Migrants in Dubai', Anthropological Quarterly 81.2 (2008), pp. 377-406. 
order to uncover "the way a diaspora is lived." 21 They argue that Indians accept the temporary nature of their stay in Oman and that their plans are always of returning home to India. Their work is important, although it does not consider the multiple ways in which Indians create homes within this diasporic space - the focus of this article.

\section{Muscat's demographics}

Muscat's complex and diverse demographics are a legacy of Oman's imperial past — when it ruled over parts of east Africa, southeast Iran, and Gwadar in southwest Pakistan — as well as its ancient trade links with India, which date back to the Iron Age. ${ }^{22}$ These international connections have endowed Muscat with a number of historic communities: Dhofaris from Oman's southern region, Zanzibaris from Zanzibar, 'Ajam from Iran, Baluch from Baluchistan, Zadjalis from Baluchistan and Sindh, Lawatiyya (who were originally Khojas) from Sindh, Kachchh ${ }^{23}$ and Gujarat, and Hindu merchants (known as Banians) from Sindh, Kachchh, and Gujarat, whose continuous presence in the city dates back at least 500 years. ${ }^{24}$ These connections are vividly evoked by William Grey's description of Muscat and Mattrah from the early twentieth century:

It was said with truth that fourteen languages are spoken daily in the bazaars of Maskat and Matrah.... The fourteen languages are Arabic, Persian, Baluchi, English, French, Swahaili, Somali, Hindustani, Sindi, Gujarati, Portuguese, Pushtu, Armenia and Turkish. .... Hindustani [is spoken] by the large bulk of the educated population; Sindi by Hindu merchants from Sind and by the Khoja community [now known as the Lawatiyya] who have within the last century settled in Oman and are rapidly coming to be regarded as part of the Arab population; Gujarati by a number of Hindu traders from the southern [sic] part of Bombay Presidency, the residence of some of whom in Oman dates back for 150 years [to the mid-eighteenth century], possibly more; Portuguese or Goanese by the Goanese population, merchants, domestic servants, etc., who number a dozen souls or more; Pushtu by Baluch and Afghan arms' dealers who are still to be met with occasionally in the bazaars.... ${ }^{25}$

${ }^{21}$ Deffner and Pfaffenbach, "Zones of Contact and Spaces of Negotiation: The Indian Diaspora in Muscat" (2011); Deffner, "The Indian Diaspora in Oman" (2014), p. 182.

${ }^{22}$ For more about Omani's empire and trade networks, see: Bhacker, Trade and Empire in Muscat and Zanzibar (1992).

${ }^{23}$ Kachchh (Kutch) State became a district of Bombay State in 1956, then a district of Gujarat State in 1960. Only since 1960, therefore, can Kachchhis be considered Gujaratis.

24 The best modern survey of Muscat's demographics is Peterson, “Oman's Diverse Society: Northern Oman”, pp. 31-51.

${ }^{25}$ Grey, “Trades and Races of Oman”, QJMS 2.2 (1911), p. 61. Grey was British Political Agent in Muscat during 1904-08. His description contains an error: Gujarat is in the western part of Bombay Presidency, not the southern part. 
The Hindu merchants came to dominate Oman's economy by the nineteenth century, owning most of the waterfront property in the old towns of Muscat and neighbouring Mattrah by the early twentieth century. This, combined with Muscat's ancient economic dependence on India, has left a significant Indian cultural imprint on the city.

In 2012, the Omani government estimated the country's expatriate population at 1,530,441, being over $40 \%$ of the total population $(3,623,001) .{ }^{26}$ The same year, the Indian government recorded 718,000 NRIs in Oman - the largest expatriate group, accounting for $46.9 \%$ of all expatriates in the country. It also recorded 642 Persons of Indian Origin (PIOs), most of whom would be Omani nationals. ${ }^{27}$ Male Omani nationals of Indian origin usually take their wives from India, who then reside in Oman on family visas. Only their children are able to inherit Omani nationality due to Oman's nationality law. They typically belong to merchant families that have resided in the country for many generations, such as the Khimji Ramdas family. They have a binational identity: part Indian, part Omani, with the latter asserted through the wearing of Omani national dress and their presence on the boards of Omani institutions. The majority of the 642 PIOs recorded in Oman in 2012 are probably Hindu, like the Khimjis. They form part of a Hindu community in Oman of c.200,000 that year (NRIs and PIOs combined), being $27.8 \%$ of all Indians in Oman. ${ }^{28}$ They play an active and leading role in the life of the country's Hindu community, and wider Indian society, especially among the professional classes.

Narrowing our focus now to Muscat, we see that over $60 \%$ of the city's population was expatriate in 2012: 658,211 out of $1,093,360 .{ }^{29}$ If $46.9 \%$ of these expatriates were Indian, as was the case at the national level that year, then there were at least 309,000 Indians in Muscat. ${ }^{30}$ These statistics are borne out by the visible presence Indians in Muscat, who appear ubiquitous. Indians permeate every level of the social scene, from a company's cleaning staff to its CEO.

The size of Muscat's Hindu working and professional classes are difficult to estimate, since the Omani government's public census data on the city does not distinguish by religion,

${ }^{26}$ Govt of Oman, National Centre for Statistics and Information, 2013 Statistical Year Book (2013), Chap. 3: Population and Housing, Sec. 2: Population, pp. 14-15.

27 Govt of India, Ministry of Overseas Indian Affairs, "Population of Non-Resident Indians: Country Wise", 12 June 2012. The number of PIOs is very close to the India govt's estimate of 600 Indian citizens in Oman in the early 1950s [Mukherjee, Our Countrymen Abroad (1954), p. 265]. It seems probable that the majority of the 642 PIOs in Oman in 2012 can trace their roots back to these 600 people sixty years before.

${ }^{28}$ Oman's Hindu population (NRIs and PIOs combined) was estimated at 5.5\% of the total population in 2010. That same percentage applied to Oman's 2012 population gives us roughly 200,000. See: Pew Research Center, “Global Religious Diversity”, 4 Apr. 2014.

${ }^{29}$ Govt of Oman, 2013 Statistical Year Book, Chap. 3: Population and Housing, Sec. 2: Population, pp. 14-15.

${ }^{30}$ Estimates have been rounded to the nearest thousand. The estimate of 309,000 Indians in Muscat is based on the nation-to-city ratio of Oman's overall expat population: 1,530,441 expats in Oman, of whom 43\% $(658,211)$ lived in Muscat. Oman's Indian population in 2012 was 718,$642 ; 43 \%$ of that is 309,000 (rounded up). 
income, or occupation. In 2010 , the Indian government estimated that about $82 \%$ of Indians in Oman (over half a million people) were blue-collared labourers, of whom 93\% were male, and just under $15 \%$ were from the professional classes. ${ }^{31}$ The remaining $3 \%$ were presumably the wealthy elite. If we apply these percentages to 2012 and assume that $27.8 \%$ of all Indians in Muscat were Hindu, as was the case at the national level that year, we arrive at a Hindu community of perhaps 86,000 , of whom 70,500 were blue-collar labourers, perhaps 12,500 were from the professional classes, and possibly 3,000 were wealthy elite. ${ }^{32}$

\section{Old Muscat and Mattrah: home of the old Banian class}

Muscat's Indian society dates back to the early sixteenth century, if not earlier, with the oldest segment being the Banian (Hindu merchant) class from Sindh, Kachchh, and Gujarat. The history of this society has been fairly well covered by historians. ${ }^{33}$ One of the most famous early descriptions of Indians in Muscat was written by the Danish explorer Carsten Niebuhr, who visited the city in 1765 . Niebuhr observed:

In no other Mahometan city are the Banians so numerous as in Maskat; their number in this city amounts to no fewer than twelve hundred. They are permitted to live agreeably to their own laws, to bring their wives with them, to set up idols in their chambers and to burn their dead. ${ }^{34}$

The fact that the Omani government permitted, and still permits, the Hindu community to cremate its dead, a practice forbidden in Islam, indicates how important and influential this community was and remains, as well as how religiously tolerant Oman's coastal society is.

31 Unpublished 2010 report by the Indian Embassy Muscat, cited in Deffner and Pfaffenbach, "Zones of Contact and Spaces of Negotiation: The Indian Diaspora in Muscat", p. 9.

${ }^{32}$ Estimates have been rounded to the nearest thousand. The $27.8 \%$ is extrapulated from the 5.5\% Hindu population for Oman overall: 200,000 out of 3,623,001 in 2012. The estimate of 86,000 Hindus in Muscat is based on the $43 \%$ nation-to-city ratio of Oman's overall expat population: $43 \%$ of 200,000 is 86,000 .

${ }^{33}$ See: Allen, "The Indian Merchant Community of Masqat", BSOAS 44.1 (1981), pp. 3953, which is based on his $\mathrm{PhD}$ dissertation, "Sayyids, Shets, and Sultāns: Politics and Trade in Musqat under the Āl bū Sa‘īd, 1785-1914” (1978); Allen, "Gokaldas Khimji: A TwentiethCentury Banyan Merchant in Muscat", presented at the AHA 2015 conference, New York, 3 Jan. 2015; Goswami, The Call of the Sea: Kachchhi Traders in Muscat and Zanzibar, c.18001880 (2012), especially chap. 2; Bhacker, Trade and Empire in Muscat and Zanzibar: Roots of British Domination (1992), which contains large sections on the Indians in Muscat; Landen, Oman since 1856: Disruptive Modernization in a Traditional Arab Society (1967), pp. $131-44$.

${ }^{34}$ Niebuhr, Travels through Arabia and Other Countries in the East, trans. Heron (1792), p. 116. 
Muscat's Banian class was predominantly Sindhi before the nineteenth century and Kachchhi from the mid-nineteenth century onwards. By 1914, it was entirely Kachchhi. In 1960, Kachchh (Kutch) was incorporated into Gujarat State, after which Kachchhis can also been considered Gujaratis. Muscat's oldest Banian families, who have resided in the city since the nineteenth century or earlier, are Bhatia Hindus from Kachchh: Khimji Ramdas, Ratansi Purshottam, Purshottam Toprani, and Jesrani (aka Dhanji Morarji). Other established Hindu families, who arrived later, include Dharamsey Nensey, Sampat, Purshottam Kanji, Shah Nagardas Manji, Madhavji Velji, Ramniklal Kothari, Gandhi, Purshottam Damodar, Jayant, Purshottam Madhavji, Laxmidas Tuaria Ved, Naranji Mirji, and Vallabhadas Tharia (see Figure 4)..$^{35}$

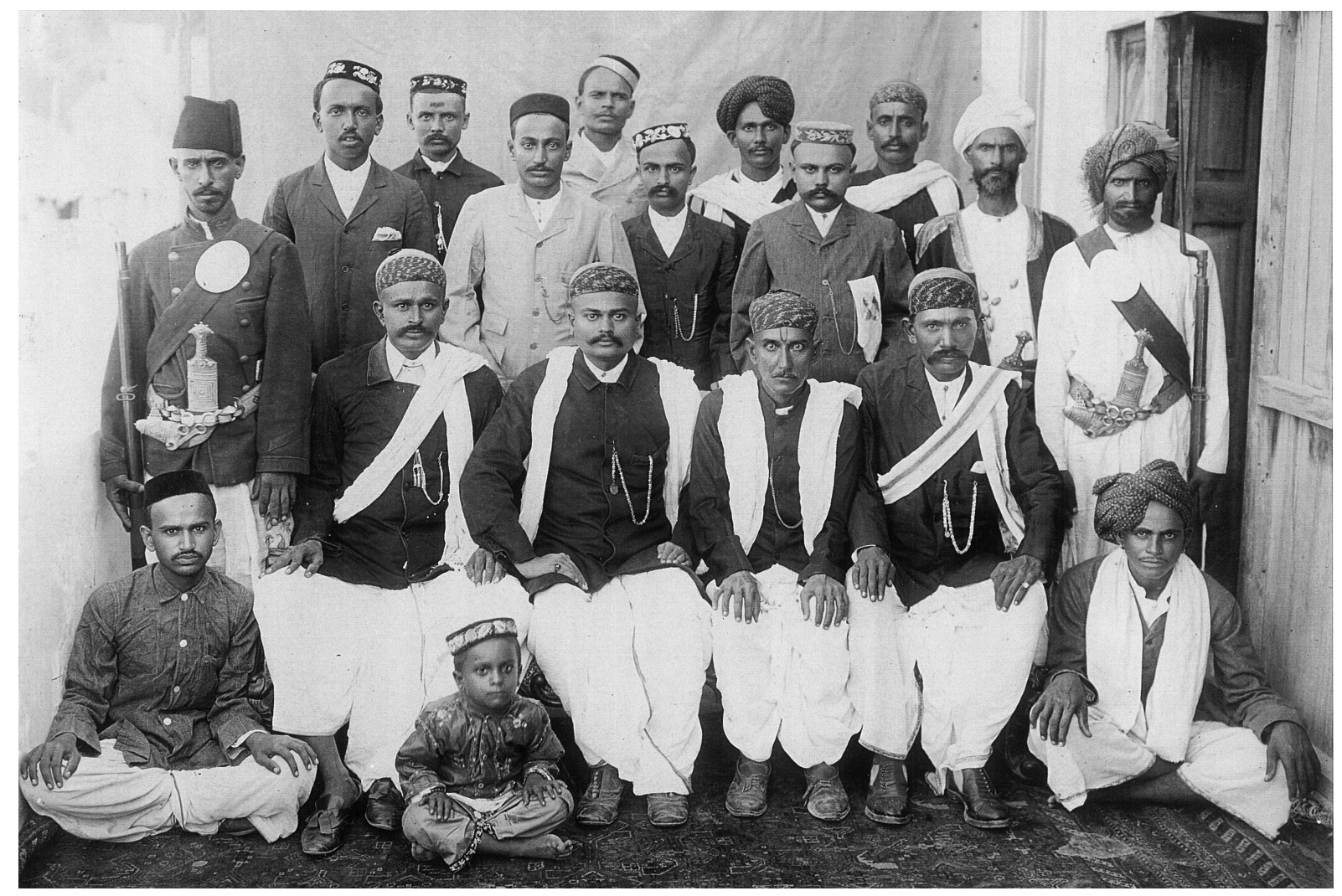

Figure 4: Owners, senior management, and staff of Messrs Ratansi Purshottam, taken in c.1910 at Bait Ratansi (Ratansi House), Old Muscat, near Qasr al-'Alam (private collection of Vimal Purecha, Partner of Ratansi Purshottam \& Co.)

The most celebrated studies of Muscat's Banian class are by Calvin Allen, who has examined at length their fluctuating fates from the sixteenth to the twentieth centuries. ${ }^{36}$ Many of these traders acquired extensive properties along Muscat's waterfront in the late nineteenth and

${ }^{35}$ Allen, "The Indian Merchant Community of Masqat?", p. 44, 46-8; Peterson, "Oman's Diverse Society: Northern Oman", pp. 38-40.

${ }^{36}$ Allen, "The Indian Merchant Community of Masqaț" (1981), pp. 40-8; "Sayyids, Shets, and Sulțāns: Politics and Trade in Musqaṭ under the Āl bū Sa‘īd, 1785-1914” (1982). 
early twentieth centuries, including the Ratansi Purshottam family firm. ${ }^{37}$ They are a physical manifestation of Oman's historical connection with, and continuing dependence on, India in many aspects of daily life. Of all the port towns of Eastern Arabia, Muscat and neighbouring Mattrah have the strongest historical, commercial, and cultural connections with the Indian subcontinent.

The majority of the old Banian class originally resided in three quarters of Old Muscat Banian and Waljat, inside the city walls, and Hawsh al-Banian (where the Shiva temple is today) outside the walls - with smaller numbers next door in Mattrah. ${ }^{38}$ Until the mid-1970s, the Banian quarter housed two Hindu temples, while the Hawsh al-Banian quarter still does, although the current temple is relatively new, standing on the site of an older one dating back to the mid-nineteenth century. In the mid-1970s, the government demolished the Banian and Waljat quarters and redeveloped them for government buildings and Sultan Qaboos' new Qasr al-'Alam ceremonial palace. ${ }^{39}$ Most of the old Banian families from these quarters relocated to Mattrah, others returned to Kachchh. Although Old Muscat now bears little resemblance to its former self, Mattrah remains much as Grey described it. It is still home to Oman's two ancient Indian merchant groups: the Khojas (aka Lawatiyya, all now Omani nationals) and the Banians (see Figure 5) ${ }^{40}$

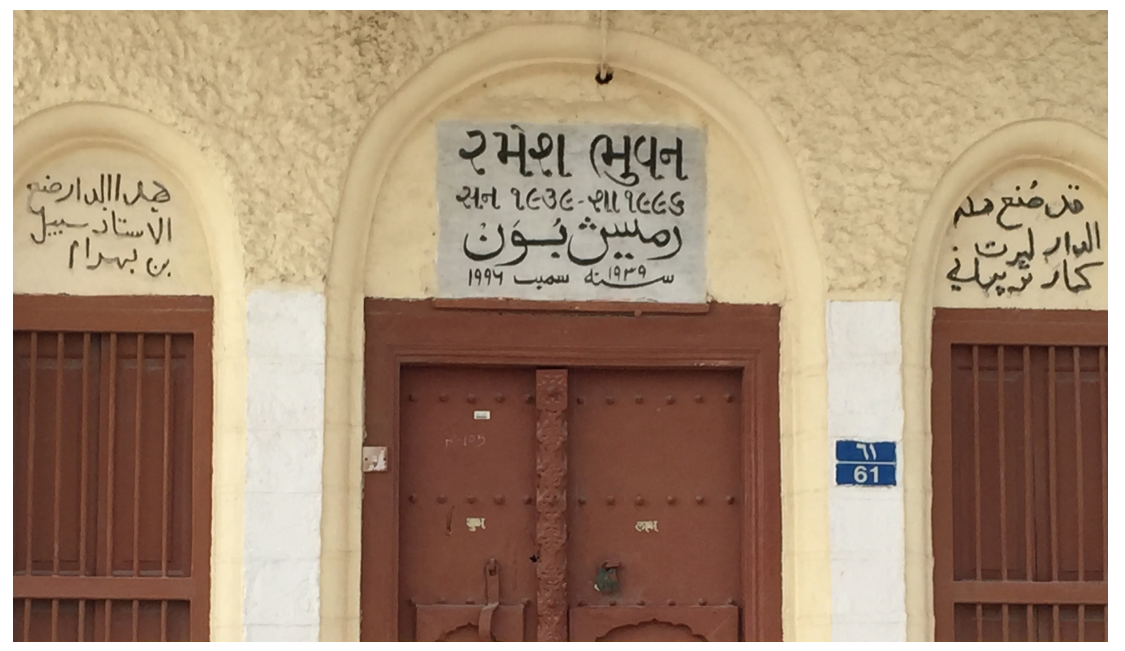

Figure 5: Ramesh Bhavan (Ramesh House), Mattrah corniche, built in 1939 by the Purshottam Toprani family (photograph by Sandhya Mehta)

37 Allen, "The Indian Merchant Community of Masqat", p. 47; Speece, "Aspects of Economic Dualism in Oman, 1830-1930”, IJMES 21.4 (1989), pp. 504-06.

${ }^{38}$ Lorimer (ed.), Gazetteer of the Persian Gulf 2: Geographical and Statistical (1908, repr. 1986), p. 1182; Peterson, Historical Muscat: An Illustrated Guide and Gazetteer (2007), pp. $39,46-7,80-1,99,113$.

${ }^{39}$ Peterson, Historical Muscat, pp. 22-7, 80-1. Qasr al-'Alam means Palace of the Flag.

40 In 1954, the Govt of India recorded 600 Indian citizens living in Oman. In 2012, it recorded 642 Persons of Indian Origin (PIOs) there, most of whom would be Omani citizens. While the size of the ancient Banian community has remained the same, the number of families may have dwindled [Mukherjee, Our Countrymen Abroad (1954), p. 265; Govt of India, "Population of Non-Resident Indians: Country Wise", 12 June 2012]. 
While the Banians' homes and shops in Mattrah's historic corniche and souq are not as numerous as those in Old Muscat before its redevelopment, they are still important. Mattrah has replaced Old Muscat as the centre of the Banian class, where the Hindu merchants continue their ancient roles as traders and shopkeepers, where Kachchhi, Gujarati, Hindi, and Urdu are heard as often as Arabic. Even the younger generation, the thirty-something youngsters on whose shoulders the continuation of the family business is placed, cherish their home in Mattrah, with its historic ties to India. One of them explained:

Mattrah is the place where I grew up. This is where all my friends met up after school was over. For me, this is who I am. I may want to explore many other opportunities elsewhere, but I know that I will come back to this [place] because, for me, this is home. $^{41}$

The Banians' sense of home in Mattrah is reinforced by the visible Indian imprint of the area's corniche and souq. ${ }^{42}$ Their homes, close to their shops, are reminiscent of historical Kachchhi/Gujarati households with traditional Indian wall hangings, furnishings, and photographs of family back in Gujarat. The families here are close knit and there are many instances of extended families of three generations (parents, children, and grandchildren), just as in Gujarat. Most send their children to India, Europe, or America to attend university, after which they often return to join the family business in Mattrah. With the nature of business changing in old Mattrah souq, some sons choose to go back to India or move to the West in response to changing market trends, while daughters more commonly marry men from their community and return to Mattrah as wives. As one such woman put it, "I am very comfortable here ... I was born here..., I can't imagine living anywhere else."

When female members of Mattrah's Gujarati Banian class were asked about what "home" meant to them, they cited the ease with which they are able to live their chosen lifestyle and observe their daily rituals, such as attending prayers at the Shiva temple in Old Muscat or the Krishna temple in Ruwi. ${ }^{43}$ Typical stories include the way in which most of these women came to Mattrah after they married and thus created a new private space for themselves within their husband's extended family. Their strong community ties, which enable them to live and support each other, ease their diasporic discomfort, especially feelings of loneliness, by enabling them to socially reproduce their homeland in Muscat. As one woman said, "we used to sleep on the terrace with the children in the summers before electricity was easily available. In the daytime, we used the terrace to roll and put out papads [an Indian savoury]." Often, the singing of folk and religious songs in Kachchhi or Gujarati would instil a sense of cultural

${ }^{41}$ For a study of the strong sense of belonging Mattrah's long-term residents feel towards their neighborhood, see Bontenbal, "Residential Satisfaction and Place Identity in a Traditional Neighborhood: The Case of Mutrah, Oman", Gateways to the World: The Rise and Fall of Port Cities in the Persian Gulf, ed. Kamrava (2016), chap. 9.

${ }^{42}$ For a study of intercultural communication between Indians and Omanis, see Mehta and Heble, "Perceptions of Indians in Oman: Exploring Aspects of Intercultural Communication", Intercultural Communication with Arabs, ed. Raddawi (2014), pp. 27-38.

${ }^{43}$ Mehta, "Gendering the Gujarati Diaspora", pp. 49-55. 
identity for the children as well. Although many of the women are still unable to work owing to legal and personal limitations, most of the younger women maintain that the comfort of living as a cultural community in Mattrah gives them a sense of security and bonds them with Muscat's wider Indian society through shared languages and customs. Their close proximity to the Shiva temple in Old Muscat and Krishna temple in Ruwi allows them to participate in religious activities frequently with other Hindus from across the city. Women often visit the temple in the mornings and accompany their families in the evenings on special religious occasions (see Figures 6 and 7).

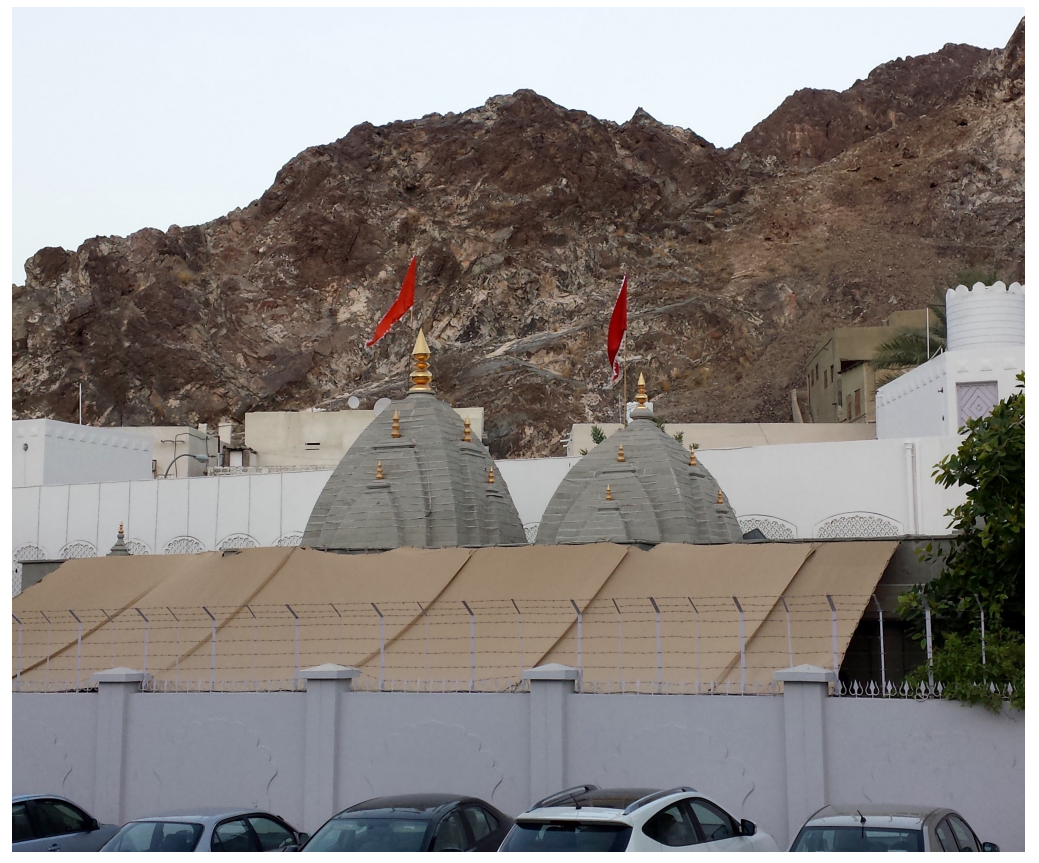

Figure 6: Outside the Shiva temple, Hawsh al-Banian quarter of Old Muscat (photograph by Sandhya Mehta)

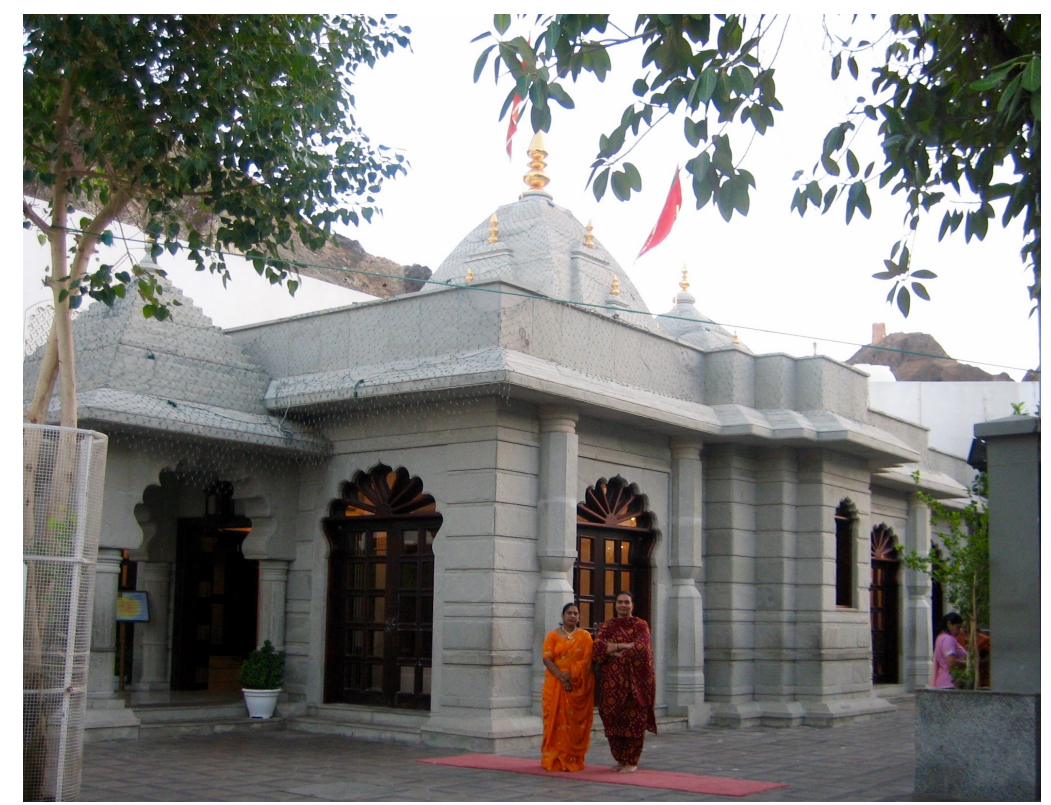

Figure 7: Inside the Shiva temple, Old Muscat

(C) Telugu Wikipedia 2006) 
The history of Muscat's Indian society, which dates back half a millennium, gives it an appearance of permanence, yet the legal status of its members is that of non-permanence: their continued presence is dependant upon an endless cycle of visa renewals. Only 642 of its three-quarter million members are Omani nationals, who are exempt from this experience. Even permanent visa holders may remain in Oman only so long as they are financially selfsufficient. If their business goes bankrupt, or they retire without an adequate pension, their visa is cancelled and they must leave Oman.

\section{Community leadership: the Khimji Ramdas family ${ }^{44}$}

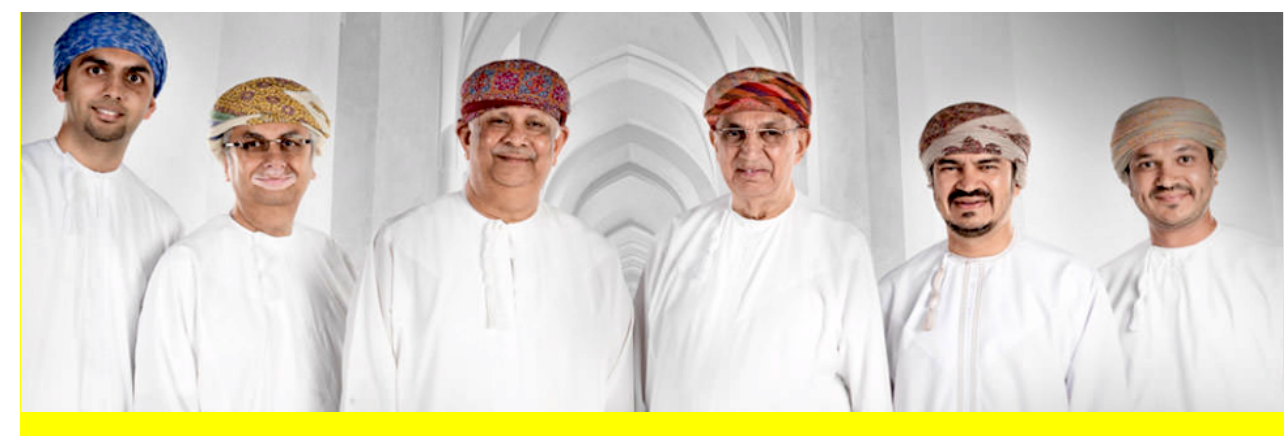

Figure 8: Khimji family (L-R): Hritik, Anjay, Anil, Kanaksi, Pankaj, and Nailesh (C) Khimji Ramdas Group) $)^{45}$

The most prominent Hindu family in Oman today is the Khimji Ramdas family: Bhatia Hindu merchants from the port of Mandvi in Kachchh, Gujarat. The family has resided in Muscat since 1870 and has Omani nationality. Their business, the Khimji Ramdas Group of Companies, has an annual turnover of US\$1 billion and conducts business in both Oman and India. It is a large business empire covering everything from supermarkets and pharmacies to shipping, importation, and construction. It also runs two of Muscat's most popular Indian restaurants: The Indus in Shatti al-Qurum and The Bollywood in Qurum (both elite neighbourhoods). Like other Omanis of Indian origin, the Khimjis wear Omani national dress in public and have a binational identity, part Omani, part Indian. They are a physical embodiment of Oman's Indian Ocean history and heritage, along with the Lawaityya, Zadjalis, Baluch, 'Ajam, and Zanzibaris. As patriarch of the family, Kanaksi Gokaldas Khimji, explained: "Though my family hails from Kachchh in Gujarat, we have always identified with Oman as our home country". ${ }^{46}$ The family has close ties to the Omani royal family through both friendship and blood. One of Kanaksi's nephews, Rishi Khimji, is married to a member of the Omani royal family — Sayyida Tania Āl Sa'îd, the daughter of

${ }^{44}$ For more about the Khimji Ramdas family, see Allen, "Gokaldas Khimji"; Khimji Ramdas family history on www.khimji.com; Shah, "The Only Hindu Sheikh of Arab World is a Gujarati”, DNA India, 26 June 2008; Parikh, "World's Only Hindu Sheikh Traces His Roots to Gujarat", Times of India, 11 May 2013.

${ }^{45}$ From the Khimji Ramdas Group website, board of directors page: www.khimji.com.

${ }^{46}$ Parikh, "World's Only Hindu Sheikh Traces His Roots to Gujarat", Times of India, 11 May 2013. 
Sayyid Shabīb bin Taimūr Āl Sa‘īid, Sultan Qaboos' youngest uncle — with whom he has a son and a daughter (see Figure 8). ${ }^{47}$

Since Kanaksi's father, Gokaldas Khimji (1901-86), assumed the chairmanship of the Hindu merchants society, the Hindu Mahajan Association, in 1939, the Khimji family has played a leading role in Oman's modern development and has helped found many Indian institutions in Muscat such as the Gujarati Medium School in Mattrah (1941), the Indian School Muscat in Ruwi (1975), the Indian Social Club in Ruwi (1977), the Oman Cricket Association (1979), and the Indian School Wadi al-Kabir (1993) — the last four being cofounded by Kanaksi Khimji. The family has been an active supporter of the Hindu community and Indian society in Oman since 1939 through the sponsorship of Hindu and Indian events, activities, and charitable work. The family also remains connected with India through commerce and charity. Aside from its business operations in New Delhi and Gujarat, it operates a charitable trust in Mandvi, which runs three schools there. ${ }^{48}$

Kanaksi Khimji, popularly known as Kanakbhai (Brother Kanak), was born in Muscat in 1936 and completed his education in Bombay. He is a Vaishnav Hindu from the Pushti Marg sect, like all Bhatias, and has an idol of Lord Shrinathji installed in a temple at his home. ${ }^{49} \mathrm{He}$ sits on the boards of many Indian and Omani institutions, and is chairman of the Hindu Mahajan Association, like his father before him, as well as the Oman-India Joint Business Council. Among other things, the Hindu Mahajan Association is responsible for maintaining Muscat's two Hindu temples and was historically responsible for Muscat's Indian schools. As chairman of the Mahajan, Kanaksi Khimji is the de facto patriarch of Oman's Hindu community of c.200,000. In recognition of that role, as well as his family's contribution to Oman's development over the past century, Sultan Qaboos awarded Kanaksi Khimji the title of shaikh. ${ }^{50}$ Sultan Qaboos has also awarded the title of shaikh to the heads of other non-tribal communities and groups in the country: the Lawatiyya (originally from Sindh and Kachchh), the Zadjalis from Baluchistan and Sindh, the Baluch from Baluchistan, the 'Ajam from Iran, and the Baharina from the central and northern Gulf. This was an extension of a government policy implemented by Sultan Qaboos soon after he came to power of officially recognising the head of every Omani tribe, community, and group by awarding him the title of shaikh altamima (or al-qabila), shaikh, and shaikh al-rashìd respectively. The role of the shaikh is to serve as an intermediary between his tribe, community, or group and the Omani

47 Buyers, "The Al-Busaid Dynasty Genealogy", www.royalark.net/Oman/oman9.htm (accessed 26 June 2015).

48 The Gokaldas Khimji Charitable Trust in Mandvi (est. 1976) operates the Khimji Ramdas Kanya Vidyalaya school (est. 1950), the Sakarbai Khimji Ramdas Memorial School (est. 1978), and the Shri Ramakrishna High School (since 1979).

49 Shah, "The Only Hindu Sheikh of Arab World is a Gujarati”, DNA India, 26 June 2008. The Pushti Marg (Path of Grace) sect, founded in the early sixteenth century, is one of seven sects within Vaishnavism. Lord Shrinathji is the sect's central presiding deity.

${ }^{50}$ Parikh, "World's Only Hindu Sheikh Traces His Roots to Gujarat", Times of India, 11 May 2013. 
government..$^{51}$

Kanaksi Khimji has also played a wider role of promoting India-GCC socio-economic relations. During his visit to Oman in 1996, the President of India, Shankar Dayal Sharma, described him as "the real ambassador of India to the Gulf countries". ${ }^{52}$ In recognition of Kanaksi Khimji's leadership in Oman, the Indian government bestowed the prestigious Pravasi Bharatiya Samman Award on him in 2003, the highest honour India can confer on a PIO for his contribution to the strengthening of bilateral relations between India and his adopted country. ${ }^{53}$ He was the first PIO in the GCC to receive this award. Since then, four other PIOs in Oman have received the award: P. Mohamed Ali (2004), P.N.C. Menon (2009), Suresh K. Virmani (2010), and Kiran Asher (2012) — the last three being members of Muscat's Hindu community.

\section{Ruwi: home of Muscat's Indian working classes}

The Banian class accounted for the majority of Indians in Oman until the arrival of oil wealth and Sultan Qaboos in 1970. Crucial to Sultan Qaboos' transformative vision for Oman were migrant labourers from India, who were attracted to Muscat in their thousands to build his dream. Most settled in Ruwi. In just a few short years, Ruwi was transformed from a sleepy village on the outskirts of Mattrah into the modern commercial district of Greater Mattrah. ${ }^{54}$ It now forms the commercial heart of Wiläyat Mattrah and is the home of Muscat's Indian working class.

All migrant labourers come to Oman alone either because they are single or because they could not meet the Omani government's minimum monthly salary requirement to sponsor their family. This minimum wage serves as a dividing line between working and professional class expatriates in Oman. Since 2013, the minimum wage is OR600 (about US\$1,550) per month. By definition, therefore, working class expatriates are without family, a fact reflected in the Omani government's preferred euphuism for male migrant labourers — "bachelors" regardless if they have wives back in India or not. A defining feature of their lives in Muscat is their painful separation from family back home, to whom they send most of their savings.

The majority of Indians in Ruwi today are semi-skilled or unskilled workers: carpenters, electricians, plumbers, maids, shopkeepers, etc. Many are on $A z \bar{a} d$ (Free) visas, an illegal system whereby an Omani national sponsors an expatriate whom he permits to work for someone else in return for an annual fee. Omani law does not permit expatriates to work for

${ }^{51}$ For more about shaikhly appointments in Oman, see: Al-Farsi, Democracy and Youth in the Middle East: Islam, Tribalism and the Rentier State in Oman (2013), p. 53; Valeri, "Domesticating Local Elites. Sheikhs, Walis and State-Building Under Sultan Qaboos", Regionalizing Oman: Political, Economic and Social Dynamics, ed. Wippel (2013), p. 272.

${ }^{52}$ Nija, "The Only Hindu Sheikh of Arab World is a Gujarati”, DNA India, 26 June 2008.

53 For more about the Pravasi Bharatiya Samman Award, confered by the Indian government's Ministry of Overseas Indian Affairs, see: www.moia.gov.in/services.aspx? $\underline{\text { mainid }=23}$.

${ }^{54}$ Peterson, "Muscat as a Port City", The Persian Gulf in Modern Times: People, Ports, and History, ed. Potter (2014), pp. 166-7. 
anyone other than their sponsors, but this law is rarely enforced because $A z \bar{a} d$ visas are an important source of income for Omani nationals. When it is enforced, as it was in November 2009, it makes headline news:

Muscat: Fear gripped workers across Oman, particularly blue-collar expatriate employees, as authorities embarked on an exercise to regularise the labour market in the country. More than 125,000 casual expatriate workers are believed to be either working in Oman on Azad (Free) visas or living in the country illegally. However, they form the backbone of the construction and transport industry. .... So far, only employees used to be punished if they were caught working outside the jurisdiction of their job profile. However, a Royal Decree recently amended the labour law and made employers accountable. The Ministry of Manpower has implemented the new regulations with a heavy hand over the past week. Raids were carried out at public places, offices, private organisations as well as specific dwellings where large groups of these workers reside. ${ }^{55}$

In spite of such recurring fears, the typical life of working class Indians in Ruwi has remained relatively unchanged in many respects for decades. Indians remit most of their savings very early in the month to their families back home, who depend on it to survive. As a result, most Indians in Ruwi have very little to live on for the rest of the month. Most of them call home on spurious (often illegal, VPN-routed) phone connections provided clandestinely by their support group of neighbours. As one electrician said, "We really live from one day to the next. I don't like holidays because there is nothing to do. I call home on the weekends, but that does not make me happy because, even then, they ask me for more money".

Single Indian women who work as maids lead an even more insular life than Indian men in these areas, for, in an aggressively male environment, many prefer to stay at home during their time off, venturing out usually just for groceries and worship. One maid had this to say: "We go to the market to get our weekly requirements. Sometimes we go to the temple, but mostly we rest, watch television, and cook for ourselves." They usually share a satellite connection and watch a variety of shows in their regional languages, occasionally venturing out to the temple or church. At times, they meet up with some of their distant relatives who may be working with other families and have also been given time off for the weekend. On special occasions such as religious festivals, they cook together, wear new clothes, and visit neighbours with gifts of food. The biggest problem these women have is the lack of transportation. One woman who works as a housemaid at the house of another Indian lady in Qurum, but who lives on her own in Ruwi, explained the problem this way: "The taxis charge whatever they feel like. There is no fixed rate...especially when they see us women alone. They are always cheating. It does not take 700 baisas [about US\$1.80] to go to the temple from here." ${ }^{56}$ Asked if she wanted to move out of Ruwi and live with her employer, she replied that "Ruwi is like our village back home [in India]. I have made some friends here and we cook, gossip, and watch TV together. Where will I find people like these? I am happy here. In Qurum, where I work, I would be very lonely."

${ }^{55}$ Vaidya, “Oman Cracks Down on 'Free Visa' Expats”, Gulf News, 30 Nov. 2009.

${ }^{56}$ Muscat does not have a public transport system and this leads to much restriction of mobility. 


\section{Wilāyat Mattrah: Muscat's Indian heartland}

The rapid expansion of Mattrah town into Ruwi in the 1970s, followed by Bayt al-Falaj, Darsait, and Wadi al-Kabir in the 1980s and 1990s, resulted in the eventual creation of Wiläyat Mattrah in 1991. As more Indians and other South Asians moved to Muscat, they relied on the recommendations of friends and acquaintances to find affordable accommodation. This resulted in the formation of South Asian concentrations in certain parts of Wilayat Mattrah, especially Ruwi. In 1977, a Roman Catholic church was built in Ruwi for the growing Indian Christian community there, followed by a Krishna temple for the Hindu community in 1987. Similarly, a service community of small retail merchants from southern India, mainly Kerala, emerged along Souq Ruwi Street (Ruwi's high street), most living above their shops with their families. Later, when new professional class residential neighbourhoods were built in Wadi al-Kabir and Darsait, Indian professionals moved into them. In response to this development in Wadi al-Kabir, a service community of mechanics and secondhand car dealers, mainly from northern India and Pakistan, also emerged there. Today, Wilayat Mattrah has the highest concentration of working and professional class Indians in Muscat: in 2009, for instance, $43 \%$ of its total population was Indian, being $68 \%$ of the expatriate population. ${ }^{57}$

A substantial Indian professional class neigbourhood also emerged in Khuwair, $12 \mathrm{~km}$ west of Ruwi in Wilayat Bawshar, where most ministries and embassies were eventually relocated. This was due in part to the large number of Indians in Omani government service: 11,944 in 2012, being one-third of all expatriates employed by the state, and the largest nationality in government service after Omanis. ${ }^{58}$ In Wiläyat Bawshar as a whole, Indians accounted for $34 \%$ of the population in 2009 , being $64 \%$ of the expatriate population. ${ }^{59}$

Due to the long historical presence of Indians in Wilayyat Mattrah, this province has the largest concentration of services for Indians, and South Asians more generally. Ruwi's large number of Indian-owned shops cater almost exclusively to South Asian tastes. The garment shops, for instance, sell clothes in keeping with the fashions and seasons in India, rather than Muscat, enabling Indians who are returning home on holiday to take gifts. Souq Ruwi Street also boasts many Indian restaurants catering to the different regional cuisines of India. Ruwi's two cinemas show only Bollywood films, at cheaper rates than cinemas in other areas, and their late shows allow workers in the neighbourhood to walk down to watch movies on the weekend. The popularity of Bollywood films in Muscat's cinemas gives some indication of Muscat's Indian demographics, as Table I shows.

57 Deffner and Pfaffenbach, "Zones of Contact and Spaces of Negotiation: The Indian Diaspora in Muscat", p. 8.

${ }^{58}$ In 2012, 5,210 Indians were employed in the Civil Service, 3,846 in the Diwan Court, 1,855 in the Royal Court, and 1,033 in the Public Authority. Indians numbered 11,944 out of 202,462 total state employees, of which 35,658 were expatriates. The second largest expatriate group was Egyptians: 7,378 [Govt of Oman, 2013 Statistical Yearbook, Chap. 4: Employment, Sec. 4: Government Sector, pp. 18, 30, 34, 40]

${ }^{59}$ Deffner and Pfaffenbach, "Zones of Contact and Spaces of Negotiation: The Indian Diaspora in Muscat", p. 8. 
Table I: Percentage of Indian films in Muscat's cinemas on 20 June 2015

\begin{tabular}{|l|l|c|}
\hline CINEMA & LOCATION & INDIAN FILMS \\
\hline City Cinema & Ruwi & $100 \%$ \\
\hline Star Cinema & Ruwi & $100 \%$ \\
\hline $\begin{array}{l}\text { Vox Cinema } \\
\text { Qurum City Centre }\end{array}$ & Qurum & $37.5 \%$ \\
\hline City Cinema & Shatti al-Qurum & $37.5 \%$ \\
\hline $\begin{array}{l}\text { City Cinema } \\
\text { Muscat Grand Mall }\end{array}$ & Khuwair & $16.6 \%$ \\
\hline $\begin{array}{l}\text { Al-Bahja Cinema } \\
\text { Markaz Al-Bahja Shopping Mall }\end{array}$ & Seeb (Mawalih North) & $50 \%$ \\
\hline $\begin{array}{l}\text { Vox Cinema } \\
\text { Muscat City Centre }\end{array}$ & Seeb (Mawalih South) & $25 \%$ \\
\hline
\end{tabular}

The nightly appearance of hawkers selling pirated films on DVDs at affordable prices further replicates the feel of an urban market in India. Indian shops sell items like emergency lamps, which are bought by many Indians to take back home as gifts for their families, owing to the frequent power cuts in almost all parts of India. Increasingly, the larger gold shops post advertisements of their products during Hindu festivals, following the practice in India. Most Indian shops and restaurants are decorated with lights during Hindu festivals such as Diwali and Onam as well as Muslim festivals. In this way, consumption patterns and public life in Ruwi is an extension of life in India.

In response to the growing size of Muscat's Indian professional class (and the South Asian professional class more generally), major supermarket chains catering to Indian tastes, such as Mars hypermarket (since 1990) and more recently Lulu hypermarket (since 2004), have opened near Indian professional class neighbourhoods in Wilāyat Mattrah, as well as newer neighbourhoods in Wiläyats Bawshar and Seeb. Most Western-style malls, such as Muscat Grand Mall in Bawshar and Muscat City Centre in Seeb, are far from the Indian heartland in Wilāyat Mattrah. Being accessible only by car, these malls are de facto professional class spaces where Indians mingle with other professional class expatriates and nationals. Ruwi's car-less working classes are restricted to short walking distances in their private time, hence the large groups of single men thronging the sidewalks of Souq Ruwi Street on weekends and public holidays for lack of anything else to do.

The emergence of Indian professional class neighbourhoods across Muscat is perhaps best illustrated by the establishment of Indian schools to service them (see Table II). Today, there are six Indian schools in Muscat and another thirteen across the country. In 2014, these nineteen schools had a student enrolment in excess of 43,000, which gives some indication of the size of Oman's Indian professional classes. All the schools are affiliated with India's Central Board of Secondary Education, which sets their curricula and exams, and are overseen by the Board of Directors of Indian Schools in Oman (see Figure 9). ${ }^{60}$

${ }^{60}$ See: www.indianschoolsoman.com. 
Table II: Indian schools in Muscat

\begin{tabular}{|l|l|l|l|}
\hline YEARS & WILĀYAH & AREA & SCHOOL \\
\hline $1941-93$ & Mattrah & Mattrah & $\begin{array}{l}\text { Gujarati Medium School (1941-87) } \\
\text { Indian School Mattrah (1987-93) }\end{array}$ \\
\hline $1975-$ & Mattrah & Ruwi & Indian School Muscat \\
\hline $1990-$ & Bawshar & Ghubra North & Indian School Al-Ghubra \\
\hline $1992-$ & Mattrah & Darsait & Indian School Darsait \\
\hline $1993-$ & Mattrah & Wadi al-Kabir & $\begin{array}{l}\text { Indian School Wadi Kabir } \\
\text { formerly the Indian School Mattrah) }\end{array}$ \\
\hline $2002-$ & Seeb & Mabella North & Indian School Al-Seeb \\
\hline $2010-$ & Seeb & Mabella South & Indian School Al-Maabela \\
\hline
\end{tabular}

\section{INDIAN SCHOOL MUSCAT}

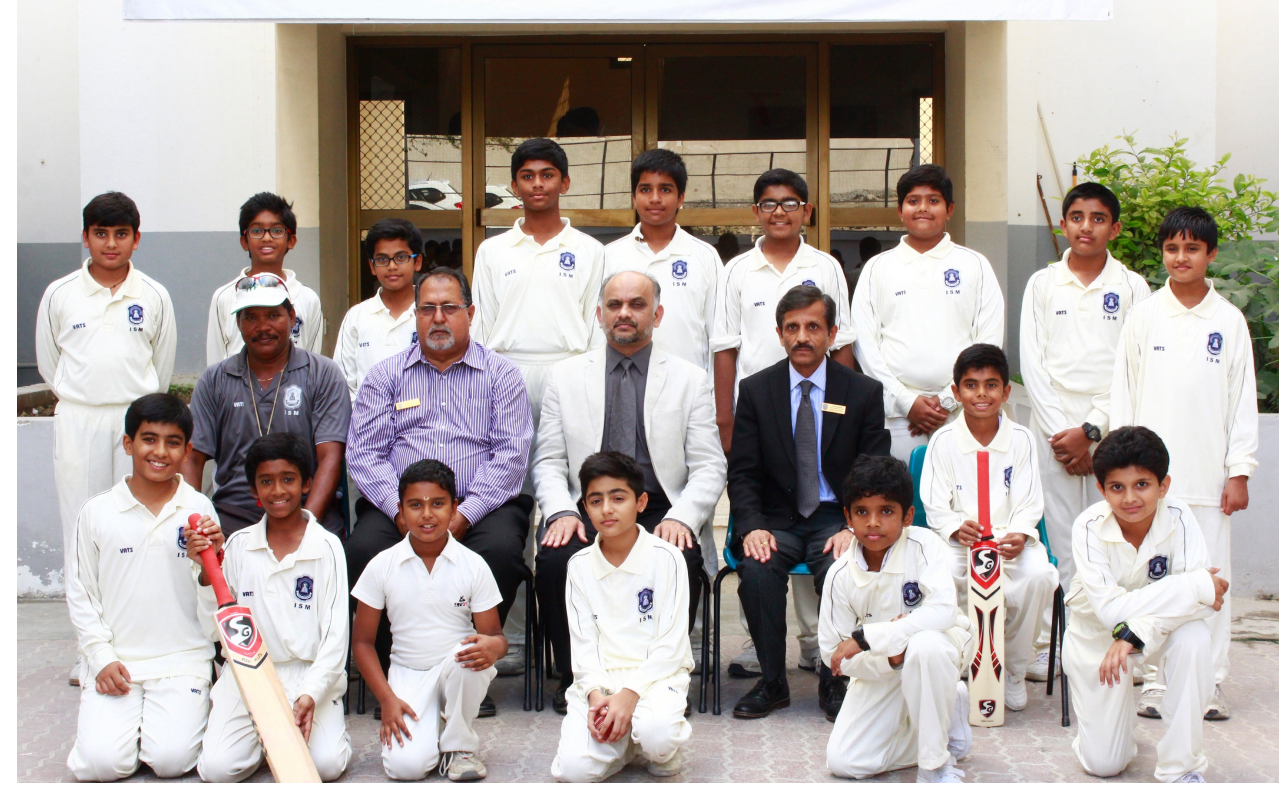

Figure 9: Indian School Muscat cricket team, Ruwi

(C) Indian School Muscat 2012)

\section{Wealthy Indian neighbourhoods: Madinat Sultan Qaboos, Qurum, Shatti al-Qurum}

Most wealthy Indians in Muscat live west of Mattrah along the coast in Qurum, Shatti alQurum, and Madinat Sultan Qaboos (Sultan Qaboos City). Madinat Qaboos, as it is known, was Muscat's first planned Western-style residential neighbourhood, built in the mid-1970s in isolation from the rest of the city:

As a planned community, it consisted of modest Western-style villas and a few apartment buildings, with a shopping complex in the center. Eventually, as land in the 
capital area became scarce, larger and more expensive houses were constructed within Madinat Qabus. ${ }^{61}$

Today, Madinat Qaboos is one of the most expensive neighbourhoods in Muscat, along with Shatti al-Qurum, and Qurum. They are comprised largely of private villas, the homes of elite professionals like doctors and senior corporate expatriates and Omanis working in oil, banking, and business - including the wealthier members of Muscat's Indian society. As Veronika Deffner observes, most of the Indian families in these neighbourhoods spend their spare time at Western-style shopping malls and high-end restaurants, and their weekends at one another's homes. They spend their holidays in India or the West, and some have Western passports from countries like Canada or Australia. ${ }^{62}$ Since the Indian government does not permit dual citizenship, they must hide it from Indian officials by keeping their Omani visas in their Indian passports. Many are also involved in religious and spiritual gatherings such as The Art of Living Foundation (founded by the Indian guru Sri Sri Ravi Shankar) and prayer groups like the International Society for Krishna Consciousness (ISKON). ${ }^{63}$ Such participation has become so popular with Muscat's Hindu professional classes that there are now several sub-groups, divided along regional and linguistic lines. Festivals are often spent visiting, or hosting parties for professional colleagues. Women in these families are working professionals; those who do not work spend much of their time visiting or participating in women's coffee mornings, known as "kitty parties", catered by the host's Indian housemaid, at which participants place money in a kitty, later drawn for in a lottery. A doctor at a public hospital who is married to a banker and stays in one of the villas in Qurum (adjacent to Wilāyat Bawshar) reflected on the typical transnational life of Indian families in this area:

My children are grown up and go to college. My son is in Canada and my daughter is studying in India, since we did not want her to go very far away from us. They visit us at least twice a year and we travel together to Europe or America on our annual holidays. We visit India in the short Eid vacations.

Other ways of sharing time include hosting and attending children's birthday parties and watching cricket matches on large television screens, often wearing the colours of one's regional team, or the Indian national team. ${ }^{64}$

Members of Muscat's professional classes are often well versed in Indian politics, which forms a regular part of their social conversations, and many subscribe to one of the two local newspapers that cover Indian news in detail, often on their front pages: the Times of Oman

${ }^{61}$ Peterson, Historical Muscat, pp. 25, 57.

${ }^{62}$ Deffner, "The Indian Diaspora in Oman", p. 188. For more about dual citizenship, see Gardner, "Strategic Transnationalism: The Indian Diasporic Elite in Contemporary Bahrain", City and Society, 20.1 (2008), pp. 56, 73.

${ }^{63}$ For more details, see www.artofliving.org and www.iskcon.com.

${ }^{64}$ The IPL (Indian Premier League) is a popular series of cricket matches in which teams represent various states of India. Increasingly, these matches have placed one state against another and loyalty to one team is actively propagated by young cricket enthusiasts in Muscat. 
and the Muscat Daily. These newspapers have a predominantly Indian readership and provide an aspect of "home" for Oman's Indian society.

\section{The lives of mid-level professionals: Khuwair, Darsait, Wadi al-Kabir}

The re-creation of a "little India" in Muscat is most evident among Indian mid-level professionals, often engineers and software specialists who come to Muscat at the start of their careers. The number of professionals coming from India is on the rise and anecdotal evidence suggests an increase in young families in the teaching sector (in schools and universities), the medical sector (as doctors in private clinics and hospitals), and the private sector where software skills are in great demand. This rise is most obvious in the growing waiting lists for entry into one of Muscat's six Indian schools. ${ }^{65}$ Most of these schools have been compelled to hold evening classes in order to accommodate the huge influx of young Indian families moving to Muscat.

Indians in professional class neighbourhoods are close knit; they typically live in modern apartment buildings overwhelmingly occupied by Indian families, which enables them to share transport for their children to attend school, to take regular shopping trips together, and even to share part-time Indian housemaids. They live mainly in nondescript buildings with four or more apartments per floor, which they decorate with auspicious religious symbols. Hindus commonly place mango leaves over their front door and a tulsi (basil) plant, considered holy, along with images of Lord Ganesha at the entrance to their homes. During festivals such as Diwali, they decorate the corridors outside their apartments with kolam patterns, indicating good luck, and light the corridor with earthern lamps or candles while exchanging sweets with their neighbours. The kolam designs are a way of engaging with one's community and creating a space of belonging. ${ }^{66}$ In this way, they convert their apartment buildings into Indian spaces of celebration (see Figure 10). One of the most common ways in which the Hindu community gets together is through weekly religious gatherings hosted at one's home, which are often followed by a religious dinner (prasad). Children are involved in these events by participating in parallel sessions of religious discourse and related activities such as religious storytelling and painting (see Figure 11).

${ }^{65}$ See, for instance: Das, "1,900 Students on Waiting List for Admission to Indian Schools in Muscat", Times of Oman, 17 Mar. 2015.

${ }^{66}$ Renate Dohmen has worked on the kolam designs outside homes in Tamil Nadu, India. She finds that the process of creating these designs was a way of engaging with one's community and creating a space of belonging: Dohmen, "The Home in the World: Women, Threshold Designs and Performative Relations in Contemporary Tamil Nadu, South India", CG 11.1 (2004), pp. 7-25. 


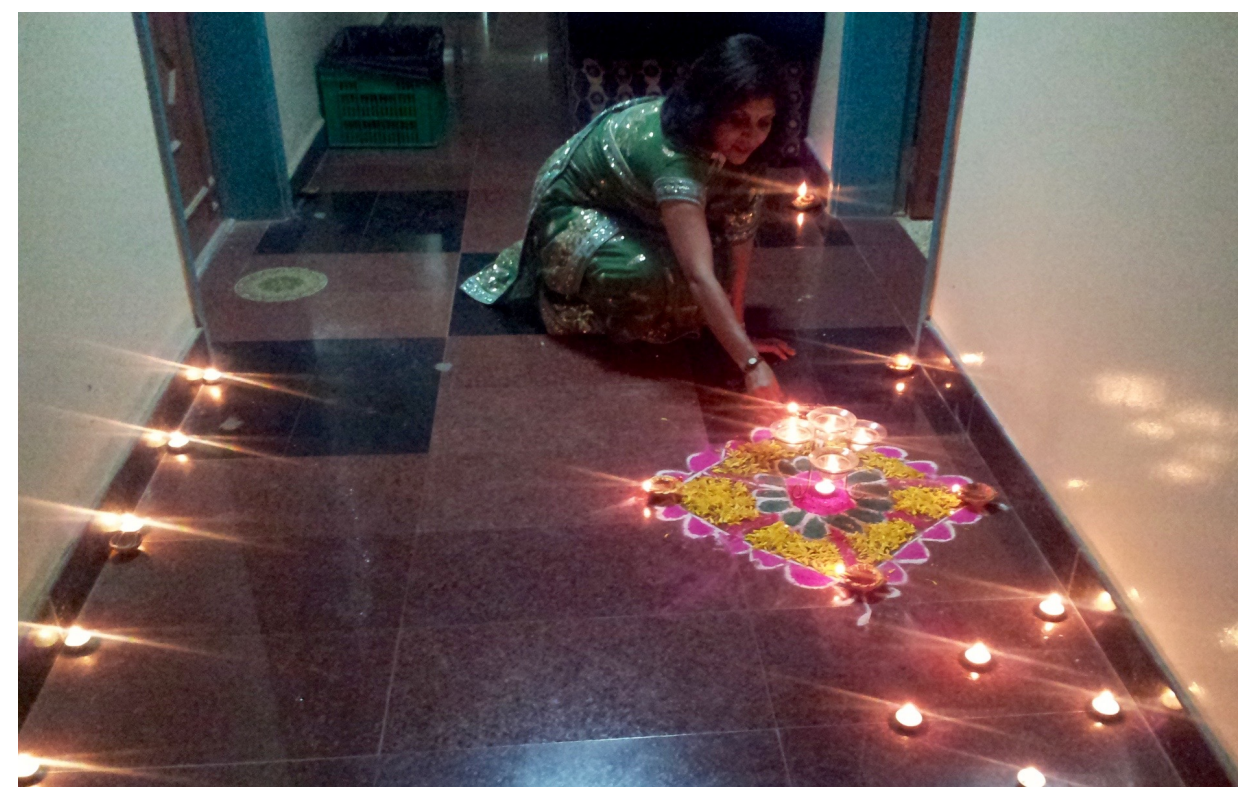

Figure 10: Kolam decoration for Diwali in an apartment corridor, Khuwair (photograph by Sandhya Mehta)

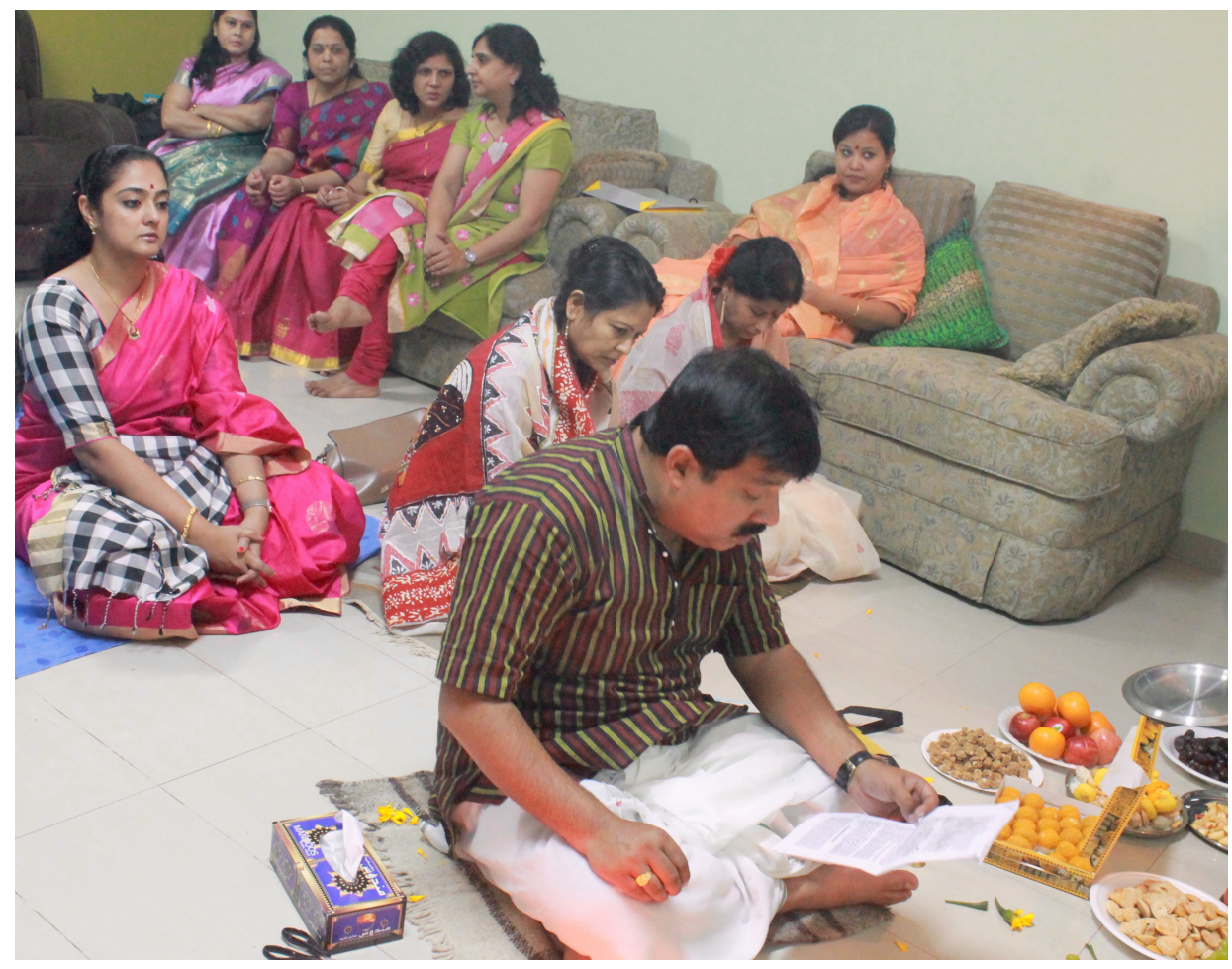

Figure 11: A Hindu prayer ceremony at an Indian home, Khuwair (photograph by Sandhya Mehta)

Increasingly, women have driving licenses and spend their evenings transporting their children to after-school classes in art, music, karate, or Indian classical dance (see Figure 
12). ${ }^{67}$ Most Indian parents regard their children's involvement in such classes as a necessity, to compensate for the opportunities lost by not living in India. Increasingly, younger couples go out to watch Bollywood movies, followed by dinner out, usually in one of the growing number of Indian restaurants in Khuwair. Some also visit pubs and discotheques with Indian DJs playing Indian pop music.

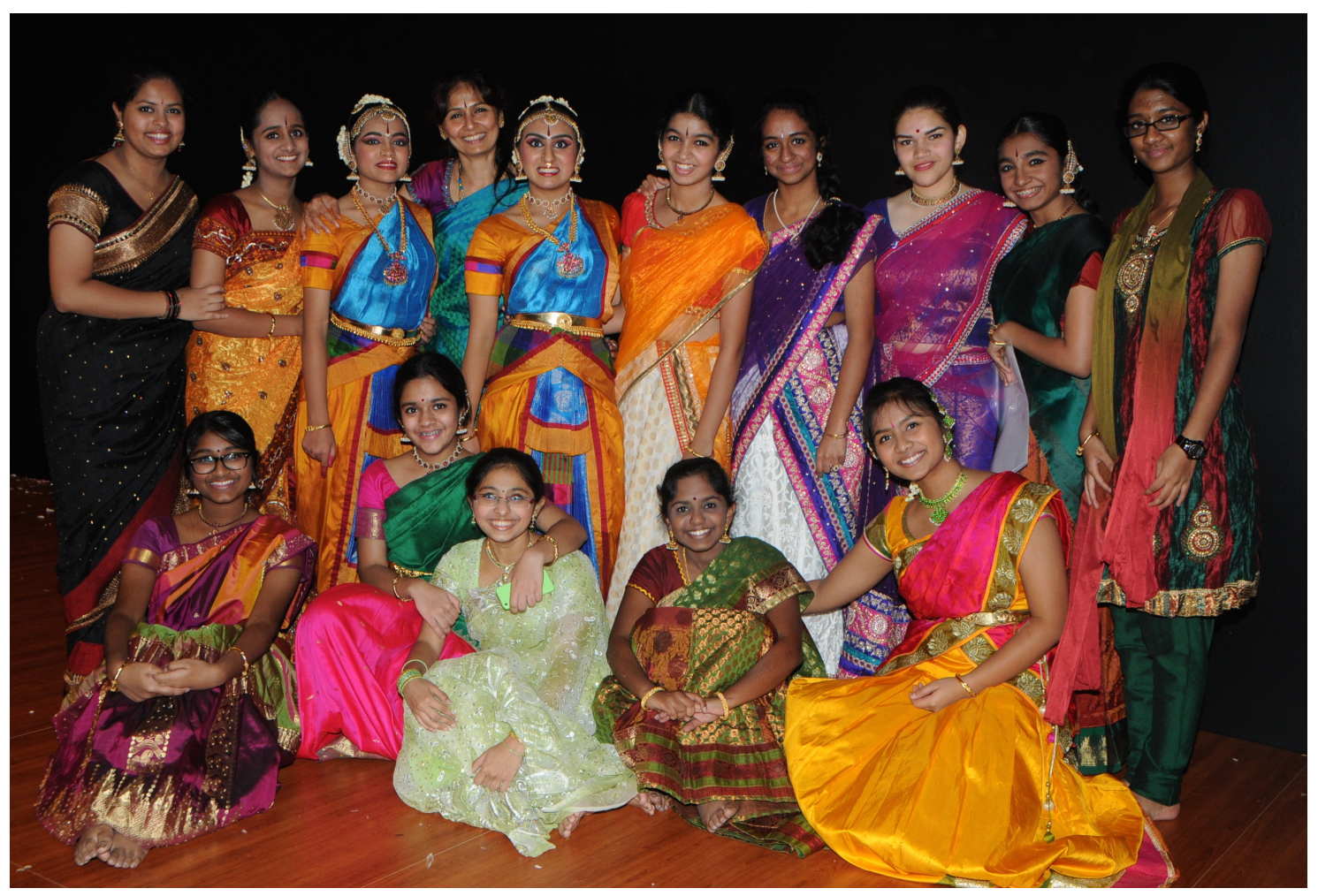

Figure 12: Nrityanjali dance academy students, Orbit Training Centre for Performing Arts, Bawshar (photograph by Sandhya Mehta)

\section{Gated communities in Wilayats Bawshar and Seeb: the new home of Muscat's Indian elite}

Very recently, Muscat's modern development has embraced the construction of gated communities in Wiläyats Bawshar and Seeb, like The Wave and Muscat Hills, in which expatriates are allowed to buy property and are given residency visas tied to it. Most of the Indians owning property in these townships are CEOs of private companies who have lived in Oman for decades and are wealthy enough to afford this lifestyle. Lately, residents have also included owners of smaller companies who are looking to invest outside India. Residence at either The Wave or Muscat Hills is regarded within Muscat's Indian society as prestigious, indicative of high status, although this is not necessarily recognised as such back in India, where few are aware of the significance of these locations. Indian residents of these gated

${ }^{67}$ Indian classical dance classes and events are orgainsed in Muscat by various institutions such as Kalamandalam Institute of Performing Arts and Harmony, as well as by individual dancers who train in India and offer lessons in classical dance forms from their homes, usually villas. 
communities do not socialise much with their non-Indian neighbours, preferring instead their Indian friends and colleagues. These wealthy Indians tend to be older and more established professionally, so their entertainment and social life is less public, limited to private gatherings at the homes of friends and colleagues. Long vacations are spent with children in different parts of the world as well as travelling, often using holiday packages specific to an Indian clientele.

\section{Emerging challenges in Muscat}

The rise of expensive residential areas in Wilayyats Bawshar and Seeb for wealthy expatriates in Muscat is part of a GCC-wide trend that is slowly changing Muscat's multicultural character to one that is self-consciously exclusive, economically determined, as well as culturally divided. In response to the Arab Spring in 2011, the Omani government introduced a number of policy changes. One such change, announced by the Muscat Municipality, was to demarcate certain beaches for families so that "bachelors" (male migrant labourers) would not be allowed. ${ }^{68}$ Citing cultural reasons, the Municipality stated that "The decision was taken following frequent complaints by families to the authorities about the lack of privacy, as most of the beaches are occupied by bachelors". ${ }^{69}$ Muscat Municipality also announced a plan to build a bachelor-only residential area for "certain categories of bachelor expatriates" to stop them from sharing or living near family accommodation. ${ }^{70}$ Although the plan has yet to be implemented, such changes will inevitably reorder Muscat's social spaces along the lines of class and ethnicity, since most of the bachelors are South Asian. The Municipality explained that "Doctors, engineers and other highly educated and professional expatriates living without families can continue to rent flats or villas" in family residential areas. ${ }^{71}$ Such proposals, along with new work visa restrictions introduced by the Omani government in 2014 namely, a two-year work visa ban for expatriates opting to change their employer (even if they have finished their contract) and a total ban on new work visas for women - may soon reorder Muscat's demographics along economic and cultural lines, forcing a re-negotiation of social spaces by expatriates for whom Muscat is home. This will be particularly true when the impact of banning expatriate women from working in Oman is felt across society, which comes on the heels of a new minimum monthly wage for family sponsorship introduced in 2013: OR600 (about US\$1,550), up from OR300 (US\$775). Such restrictions threaten to break up Indian families and homes in Muscat.

${ }^{68}$ Responsibility for the Muscat metropolitan area is divided between the Governorate of Muscat and the Muscat Municipality. The Municipality is responsible for urban planning and development, housing, parks, beaches, and so on. See: $\underline{\text { www.mm.gov.om }}$ and www.mmc.gov.om.

${ }^{69}$ Al Mukrashi, "Families Happy at Oman's Bachelor-Free Beach Zone”, Times of Oman, 21 June 2014, p. 3.

${ }^{70}$ Al Ghadani, "Muscat Municipality Plans Separate Zone for Expatriate Bachelors in Oman", Times of Oman, 18 May 2014, p. 3.

${ }^{71}$ Al Ghadani, "Muscat Municipality", p. 3. 


\section{Conclusion}

In her study of diasporic homes, Sara Ahmed suggests that "Home is here, not a particular place that one simply inhabits, but more than one place; there are too many homes...." This idea, along with a diaspora's Janus (two-faced) conception of "home", with one face looking back to the homeland and the other looking forward to a future abroad, is a helpful way of seeing Muscat's Indian society. Unlike some diasporas, Indians in Muscat are not prevented from returning to India. Indeed, professional class Indians return annually on average, visiting family and preparing a home for their eventual retirement. Those who remain in Oman past retirement tend to be from long-established families in Oman on permanent visas, including the wealthy elite.

Yet, the fact that the majority of Indians in Muscat eventually return to India has not prevented them from dominating the spaces they occupy, owning them in cultural and social terms, making them more Indian than Omani - a home away from home, even an extension of India itself. But increasing urbanization and contemporary political and social pressures are making it difficult for Indians to sustain their home-making strategies. The family restrictions on expatriate men earning less than OR600 a month, combined with the new ban on expatriate women working, will make it nearly impossible for most low-level professionals to live in Muscat with their families in the future, just like their blue-collar compatriots. The number of Indian "homes" in Muscat appears set to decline. The development of the city over the last decade has culminated in the creation of economically-determined social spaces with a clear ethnic dimension in the case of labourers. With the government's increasing proposals to segregate Muscat's social spaces, the city's Indian blue-collar workers will become as isolated from wider society as they have already become in other GCC cities. The proposals, when implemented, may adversely affect the fabric of Indian society. This, in turn, will likely see Indians adopting new strategies to create and maintain diasporic homes in Muscat and new ways of connecting with each other, however challenging that may be.

\section{Bibliography}

Abraham, Rhea, "India and its Diaspora in the Arab Gulf Countries: Tapping into Effective 'Soft Power' and Related Public Diplomacy”, Diaspora Studies 5.2 (2012), pp. 124-46.

Al-Farsi, Sulaiman, Democracy and Youth in the Middle East: Islam, Tribalism and the Rentier State in Oman (London: I.B. Tauis, 2013).

Al Ghadani, Fahad, "Ban on Recruiting Expatriates Proposed for 'Negative' Nationalities in Oman", Times of Oman, 7 May 2014, p. 3.

- "Muscat Municipality Plans Separate Zone for Expatriate Bachelors in Oman", Times of Oman, 18 May 2014, p. 1.

Ali, Syed, Dubai: Gilded Cage (New Haven: Yale University Press, 2010).

Al Mukrashi, Fahad, "Families Happy at Oman's Bachelor-Free Beach Zone", Times of Oman, 21 June 2014, p. 3.

Allen, Calvin. Jr., "Sayyids, Shets, and Sulțāns: Politics and Trade in Musqaṭ under the Āl bū Sa'īd, 1785-1914" (PhD dissertation, University of Washington, 1978).

, "The Indian Merchant Community of Masqat", Bulletin of the School of Oriental and African Studies 44.1 (1981), pp. 39-53. 
, "Gokaldas Khimji: A Twentieth-Century Banyan Merchant in Muscat", presented at the American Historical Association conference, New York, on 3 January 2015.

Attiyah, Hamid S., "Expatriate Acculturation in Arab Gulf Countries", Journal of Management Development 15.5 (1996), pp. 37-47.

Bauböck, Rainer, and Thomas Faist (eds), Diaspora and Transnationalism: Concepts, Theories and Methods (Amsterdam: Amsterdam University Press, 2010).

Bhacker, M. Redha, Trade and Empire in Muscat and Zanzibar: Roots of British Domination (London: Routledge, 1992).

Blunt, Alison, "Cultural Geography: Cultural Geographies of Home", Progress in Human Geography 29.4 (2005) pp. 505-15.

Bontenbal, Marike, "Residential Satisfaction and Place Identity in a Traditional Neighborhood: The Case of Mutrah, Oman", Gateways to the World: The Rise and Fall of Port Cities in the Persian Gulf, edited by Mehran Kamrava (London: Hurst \& Co., 2016), chapter 9.

Buyers, Christopher, "The Al-Busaid Dynasty Genealogy", www.royalark.net/Oman/ oman9.htm (accessed 26 June 2015).

Cohen, Robin, Global Diasporas: An Introduction, 2nd edn (London: Routledge, 2008).

Das, Rahul, "1,900 Students on Waiting List for Admission to Indian Schools in Muscat", Times of Oman, 17 March 2015.

Deffner, Veronika, “The Indian Diaspora in Oman”, India Migration Report 2014: Diaspora and Development, edited by S. Irudaya Rajan (New Delhi: Routledge, 2014), pp. 181-92.

and Carmella Pfaffenbach, "Zones of Contact and Spaces of Negotiation: The Indian Diaspora in Muscat (Sultanate of Oman)", paper presented at the Research Committee on Urban and Regional Development (RC21) 2011 Conference held in Amsterdam, 7-9 July 2011, available online at www.rc21.org/conferences/amsterdam2011/ edocs/Session\%2028/28-DP-Deffner.pdf.

Dito, Mohammed, "Kafala: Foundations of Migrant Exclusion in GCC Labour Markets", Transit States: Labour, Migration \& Citizenship in the Gulf, edited by Abdulhadi Khalaf, Omar AlShehabi, and Adam Hanieh (London: Puto Press, 2015), pp. 79-100.

Dohmen, Renate, "The Home in the World: Women, Threshold Designs and Performative Relations in Contemporary Tamil Nadu, South India", Cultural Geographies 11.1 (January 2004), pp. 7-25.

Dresch, Paul, "Foreign Matter: The Place of Strangers in Gulf Society", Globalization and the Gulf, edited by John W. Fox, Nada Mourtada-Sabba and Mohammed Al-Mutawa (New York: Routledge, 2006), pp. 200-22.

Faist, Thomas, "Introducation", Diaspora and Transnationalism: Concepts, Theories and Methods, edited by Rainer Bauböck and Thomas Faist (Amsterdam: Amsterdam University Press, 2010), pp. 9-34.

Gardner, Andrew, "Strategic Transnationalism: The Indian Diasporic Elite in Contemporary Bahrain", City and Society, 20.1 (2008), pp. 54-78.

- City of Strangers: Gulf Migration and the Indian Community in Bahrain (Ithaca: Cornell University Press, 2010).

Grey, William G., "Trades and Races of Oman," Quarterly Journal of the Mythic Society 2.2 (January 1911), pp. 60-1. 
Government of India, Ministry of Overseas Indian Affairs, "Population of Non-Resident Indians: Country Wise", 12 June 2012, available online at http://moia.gov.in/writereaddata/ pdf/NRISPIOS-Data \%2815-06-12\%29new.pdf.

Government of Oman, National Centre for Statistics and Information, 2013 Statistical Year Book, available at www.ncsi.gov.om.

Goswami, Chhaya, The Call of the Sea: Kachchhi Traders in Muscat and Zanzibar, c.1800 1880 (New Delhi: Orient Black Swan, 2012).

Hua, Anh, "Homing Desire, Cultural Citizenship, and Diasporic Imaginings", Journal of International Women's Studies 12.4 (2011), pp. 45-55.

Jain, Prakash C. and Ginu Zacharia Oommen (eds), South Asian Migration to Gulf Countries: History, Policies, Development (Delhi: Routledge India, 2015).

Landen, Robert Geran, Oman since 1856: Disruptive Modernization in a Traditional Arab Society (Princeton: Princeton University Press, 1967).

Lorimer, John G. (ed.), Gazetteer of the Persian Gulf 2: Geographical and Statistical (Calcutta: Superintendent of Government Printing, 1908; reprinted by Archive Editions, 1986).

Mehta, Sandhya Rao, "Gendering the Gujarati Diaspora: Oral Narratives and Identity", Globalisation, Diaspora and Belonging: Exploring Transnationalism and Gujarati Identity, edited by Sharmina Mawani and Anjoom Mukadam (Jaipur: Rawat Publications, 2014), pp. 42-57.

— "Exploring 'Marginal' Diasporas: Indians in the Middle East", Dynamics of Diasporic Identity in Commonwealth Literature, edited by Arvind Nawale and Nibedita Mukherjee (New Delhi: AuthorsPress, 2013), pp. 258-78.

- and Ayesha Heble, "Perceptions of Indians in Oman: Exploring Aspects of Intercultural Communication", Intercultural Communication with Arabs, edited by Rana Raddawi (London: Springer, 2014), pp. 27-38.

Mukherjee, Kumari Mukul, Our Countrymen Abroad (New Delhi: Indian National Congress, 1954).

Niebuhr, Carsten, Travels through Arabia and Other Countries in the East, trans. Robert Heron (Edinburgh: R. Morrison \& Son, 1792; translated from the original 1772 German edition).

Onley, James, "Indian Communities in the Persian Gulf, c.1500-1947”, The Persian Gulf in Modern Times: Ports, Peoples and History, edited by Lawrence G. Potter (London: Palgrave Macmillan, 2014), pp. 231-66.

Parikh, Runa Mukherjee, "World's Only Hindu Sheikh Traces His Roots to Gujarat", Times of India, 11 May 2013.

Peterson, J.E., “Oman's Diverse Society: Northern Oman”, Middle East Journal 58.1 (Winter 2004), pp. 31-51.

- Historical Muscat: An Illustrated Guide and Gazetteer (Leiden: Brill, 2007). , "Muscat as a Port City", The Persian Gulf in Modern Times: People, Ports, and History, edited by Lawrence G. Potter (London: Palgrave Macmillan, 2014), pp. 153-72.

Pradhan, Samir, "Oman-India Relations: Exploring the Long-Term Migration Dynamics", Regionalizing Oman: Political, Economic and Social Dynamics, edited by Steffen Wippel (Dordrecht, Netherlands: Springer, 2013), pp. 107-28.

Pew Research Center, "Global Religious Diversity", 4 April 2014, available online at www.pewforum.org/files/2014/04/Religious-Diversity-full-report.pdf. 
Rajan, Irudaya, S. (ed.), India Migration Report 2014: Diaspora and Development (New Delhi: Routledge, 2014).

Safran, William, "Diasporas in Modern Societies: Myths of Homeland and Return", Diaspora: A Journal of Transnational Studies 1.1 (1991), pp. 83-99.

Shah, Nija, "The Only Hindu Sheikh of Arab World is a Gujarati", DNA (Daily News and Analysis) India, 26 June 2008, available online at www.dnaindia.com.

Sheller, Mimi, "The New Mobilities Paradigm for a Live Sociology", Current Sociology Review 62.6 (2014), pp. 789-811, available at http://csi.sagepub.com.

Speece, Mark, “Aspects of Economic Dualism in Oman, 1830-1930”, International Journal of Middle East Studies 21.4 (1989), pp. 495-515.

Tölölyan, Khachig, "The Nation-State and Others: In Lieu of a Preface", Diaspora: A Journal for Transnational Studies 1.1 (Spring 1991), pp. 3-7.

Vaidya, Sunil K. "Oman Cracks Down on 'Free Visa' Expats", Gulf News, 30 November 2009.

Valeri, Marc, "Domesticating Local Elites. Sheikhs, Walis and State-Building Under Sultan Qaboos", Regionalizing Oman: Political, Economic and Social Dynamics, edited by Steffen Wippel (Dordrecht, Netherlands: Springer, 2013), pp. 267-77.

Vora, Neha, "Producing Diasporas and Globalization: Indian Middle-Class Migrants in Dubai', Anthropological Quarterly 81.2 (Spring 2008), pp. 377-406.

- Impossible Citizens: Dubai's Indian Diaspora (New York: Duke University Press, 2013).

Weiner, Myron, "International Migration and Development: Indians in the Persian Gulf", Population and Development Review 8.1 (1982), pp. 1-36.

Wippel, Steffen (ed.), Regionalizing Oman: Political, Economic and Social Dynamics (Dordrecht, Netherlands: Springer, 2013).

Winckler, Onn, "The Challenge of Foreign Workers in the Persian/Arabian Gulf: The Case of Oman”, Immigrants \& Minorities 19.2 (July 2000), pp. 23-52. 